\title{
Cosmoramas, dioramas, panoramas e fantasmagorias como dispositivos de imersão na Campos dos Goytacazes do século XIX.
}

Autor: Tiago Bravo Pinheiro de Freitas Quintes

\section{RESUMO}

O trabalho busca investigar a percepção do público sobre as apresentações audiovisuais pré cinematográficas que ocorreram no município de Campos dos Goytacazes durante o século XIX. As atrações pesquisadas são os cosmoramas, dioramas, panoramas e as fantasmagorias, divertimentos que fizeram muito sucesso na Europa. Alguns, principalmente os cosmoramas e as fantasmagorias, também alcançaram repercussão importante em grandes centros urbanos do Brasil. O intuito é analisar estas atrações e buscar as semelhanças e diferenças entre os dispositivos de imersão no que diz respeito a questões sobre a tecnologia imersiva e principalmente sobre a experiência do observador. A pesquisa procura ainda relacionar a raiz midiática destas atrações à mesma raiz do que viria a torna-se o cinema, detalhando possíveis gêneros encontrados naquelas antigas exibições.

PALAVRAS CHAVE: Arqueologia do Cinema; Campos dos Goytacazes; Século XIX 


\section{SUMÁRIO}

BASE TEÓRICA E METODOLOGIA DE PESQUISA ......................................03

DADOS GEOGRÁFICOS E CULTURAIS SOBRE CAMPOS DOS GOYTACAZES...05 DADOS HISTÓRICOS SOBRE CAMPOS DOS GOYTACAZES.............................06

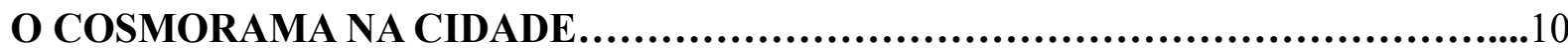

DIORAMAS E COSMORAMAS EM CAMPOS DOS GOYTACAZES......................15 FANTASMAGORIAS, PRESTIDIGITADORES E KALEIDOSCÓPIOS...................24

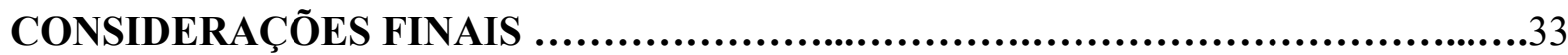

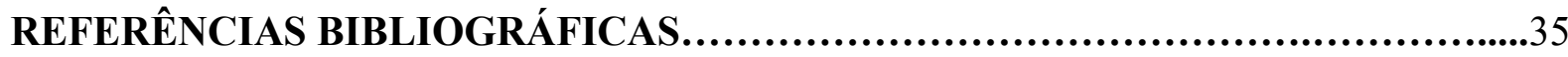

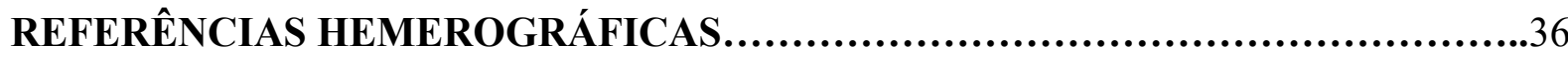

ANEXO A - ANÚNCIOS DE COSMORAMAS..............................................37

ANEXO B - ANÚNCIOS DE DIORAMAS E PANORAMAS...............................40 ANEXO C - ANÚNCIOS DE PRESTIDIGITADORES E FANTASMAGORIAS...........41 


\section{BASE TEÓRICA E METODOLOGIA DE PESQUISA}

A base teórica utilizada no intuito de trazer esclarecimentos sobre os dispositivos tecnológicos foram os trabalhos dos autores MANONNI (2003) e HUHTAMMO (2013). As publicações destes estudiosos auxiliam na busca da compreensão sobre o contexto histórico em que estes divertimentos aconteciam e na relação dos dispositivos com o sujeito humano.

Para a melhor compreensão daqueles divertimentos imersivos no contexto do povo brasileiro e fluminense serão utilizados os textos de GONZAGA (1996) e ARAÚJO (1976). Apesar de relatos passageiros, percebe-se aqui a importância destes trabalhos para a tentativa de traçar características da cultura e dos costumes do observador brasileiro e especificamente do povo do estado do Rio de Janeiro.

A subjetividade do olhar do observador daquelas atrações é pesquisada e abordada principalmente com base nos estudos de CRARY (2015) e também nas ideias de FELINTO (2008). CRARY (2015) faz a ligação teórica e tecnológica da câmara escura com a lanterna mágica, o panorama e outros aparatos do século XIX e percebe-os como dispositivos que de certa maneira visavam o domínio dos corpos humanos.

O trabalho de PETERSON (2008) auxilia no entendimento sobre os gêneros educativos e “de viagem” em mídias pré cinema e também numa melhor compreensão sobre a cultura do gênero "travelogue". FELINTO (2008) traz importantes reflexões sobre o que chama de "fantasmagoria tecnológica" e dá exemplos da ligação desta alegoria com a comunicação e o cinema.

O modus operandi de toda a pesquisa e da escrita está baseado no estudo de ELSAESSER (2018) sobre o cinema como arqueologia das mídias. O trabalho do autor é também diretamente utilizado com a finalidade de entrelaçar as raízes das mídias do passado, do presente e do futuro. 
De início esta pesquisa contextualiza o município de Campos dos Goytacazes de forma geográfica e histórica. Esta introdução servirá para um maior entendimento sobre o espaço físico do qual trata-se este trabalho. Para a formulação da base histórica foram utilizadas as publicações de historiadores campistas PAIXÃO (1919), SOUZA (2014) e RODRIGUES (1988). Outro trabalho que serviu de grande referência para traçar o passado de Campos dos Goytacazes e o perfil dos campistas foi SAINT-HILAIRE (1941), publicação baseada nos escritos de viagem do naturalista francês pelo Brasil entre 1816 e 1820 .

Na escavação de relatos sobre as apresentações em Campos dos Goytacazes a pesquisa baseia-se em anúncios e reportagens de jornais com sede no município. Nota-se a circulação de jornal impresso em Campos desde 1831, este era o Correio Campista. O jornal mais antigo ainda acessível para consulta é $O$ Recopilador Campista, fundado em 1837 e que depois fundiu-se ao jornal O Monitor, transformando-se no Monitor Campista (SOUZA, 2014). O Monitor Campista é um dos periódicos mais longevos do país ${ }^{1}$. Muitas edições deste jornal estão disponíveis na Hemeroteca Digital da Biblioteca Nacional. Outras edições do periódico podem ser consultadas presencialmente no Arquivo Público Municipal Waldir Pinto de Carvalho e na sede da Biblioteca Nacional.

Outro periódico utilizado pra a formulação da pesquisa é o Gazeta do Povo, que foi inaugurado em 1881 e findou-se no início do século XX. Do jornal extraiu-se alguns anúncios e relatos sobre prestidigitadores e apresentações de fantasmagorias. As edições utilizadas estavam disponíveis para a consulta presencial na Biblioteca Nacional.

Todos os anúncios que foram comentados durante o texto, tanto do Gazeta do Povo quanto do Monitor Campista, são reproduzidos na área de anexos da maneira como foram publicados para que se tenha maior entendimento sobre os assuntos e fatos abordados.

1 - O Monitor Campista ficou em atividade de 1840 a 2009. Em 2017 a Associação de Imprensa Campista e a Prefeitura Municipal de Campos dos Goytacazes sinalizaram trabalhar em uma possível volta, o que não se concretizou. Fonte: https:// www.campos.rj.gov.br/exibirNoticia.php?id noticia $=40490$ Acesso: 31/01/2020 


\section{DADOS GEOGRÁFICOS E CULTURAIS SOBRE CAMPOS DOS}

\section{GOYTACAZES}

Campos dos Goytacazes é um município localizado na região Norte do Estado do Rio de Janeiro, atualmente possui uma população estimada em aproximadamente 507 mil habitantes e seu território corresponde a 4.031,989 $\mathrm{Km}^{2}$. O município é o maior do Rio de Janeiro em extensão, maior até mesmo do que a capital do estado ${ }^{2}$. Sua área é formada, na maior parte, por uma grande planície e no centro desta está localizada a cidade. O município também possui diversas regiões rurais em volta de toda a planície, área litorânea (Farol de São Tomé) e áreas montanhosas (região do Imbé) com lagoas e cachoeiras. Os municípios limítrofes de Campos dos Goytacazes são: São Francisco de Itabapoana, São João da Barra, Quissamã, São Fidélis, Cardoso Moreira, Italva, Bom Jesus do Itabapoana e Mimoso do Sul (ES).

A economia do município é baseada desde a década de 1970 na extração do petróleo em alto-mar, na Bacia de Campos. A indústria da pecuária e a agricultura familiar também são de grande importância para o município e região. Outra forte característica econômica de Campos dos Goytacazes é o plantio e processamento da cana-de-açúcar para a produção de álcool e derivados. Este tipo de indústria foi implantada pelos portugueses ainda no século XVIII, com os antigos engenhos, e perdurou como base econômica da cidade durante quase 200 anos. A indústria da cana passou por um colapso com o boom do petróleo e atualmente observa-se novo crescimento no número de usinas em funcionamento no município.

Segundo levantamento realizado para a pesquisa, o município de Campos dos Goytacazes possui no ano de 2020 os seguintes equipamentos culturais: 04 teatros, 10 salas de cinema (todas localizadas em Shopping Centers), 06 casas ou espaços de cultura, 03 bibliotecas públicas e o centro de divertimentos infantis mantidos pela prefeitura municipal

2 - https://cidades.ibge.gov.br/brasil/ri/campos-dos-goytacazes/panorama . Acesso: 31/01/2020 
chamado Cidade da Criança. A cidade ainda conta o Museu Histórico de Campos e o Arquivo Público Municipal Waldir Pinto de Carvalho, ambos também mantidos pela prefeitura. O Palácio da Cultura (também municipal) foi um importante espaço de exposição, salvaguarda e pesquisa da arte e da cultura campista, porém encontra-se fechado para obras desde 2014 e sem previsão de conclusão ${ }^{3}$.

A prefeitura municipal também possui desde 2012 o aparato cultural Centro de Eventos Populares Osório Peixoto, o Cepop ${ }^{4}$, uma grande área pavimentada que conta com um estacionamento, arquibancadas, camarotes, camarins, praça de alimentação, área médica, uma avenida pavimentada e no final desta uma arena com um imenso palco fixo. A área é utilizada como sambódromo para o desfile das escolas de samba de Campos dos Goytacazes e também já abrigou grandes shows nacionais e algumas edições da bienal do livro de Campos.

\section{DADOS HISTÓRICOS SOBRE CAMPOS DOS GOYTACAZES}

Grande parte do que atualmente compreende-se como região Norte-Fluminense era território habitado pela nação indígena dos Goitacás. Os indígenas desta região resistiram à invasão portuguesa até o século XVIII, quando foram praticamente extintos. No território onde hoje é o município de Campos, além dos próprios Goitacás, também encontravam-se indígenas Guarulhos e Puris. SAINT-HILAIRE (1941) destaca que o povo "goytacá” "não falava absolutamente a "língua geral"” e era conhecido como "os mais selvagens e cruéis do litoral do Brasil”".

3 - Em 2018 a Prefeitura Municipal anunciou a retomada das obras. Os ônus seriam provenientes de uma medida compensatória contra uma construtora condenada por derrubar um prédio histórico na cidade. Na prática a retomada nunca aconteceu. Fonte: https:// g1.globo.com/rj/norte-fluminense/noticia/2018/08/18/obras-do-palacio-da-cultura-em-campos-rj-serao-retomadas-apos-dois-anosparalisadas.ghtml . Acesso: 31/01/2020

4 - Fonte: http://mapadecultura.ri.gov.br/manchete/centro-de-eventos-populares-osorio-peixoto Acesso: 31/01/2020 
Muitas são as tentativas de explicação para a denominação "goytacá”. A mais provável é sobre o nome ter origem entre os Aimorés, um povo indígena que temia os Goytacás. A palavra seria uma junção de “'Goya' (prefixo de goiamun, caranguejo grande do brejo) e tacá (lembrando taca pé, do tupi, portanto 'matar'). Significaria 'caranguejo grande que mata"' (RODRIGUES, 1988, p.18).

Os portugueses demarcaram a região em 1533 como Capitania de São Thomé, entregue aos domínios de Pero de Góis. Este tentou ocupar o local com tudo o que tinha de material, pessoal, armas e animais, mas foi expulso pelos indígenas. Cem anos passaram-se e em 1630 os portugueses formaram uma liga com homens da capital Rio de Janeiro, Cabo Frio e outras localidades e empreenderam uma intensa batalha para expulsar os Goitacás da região. Nesta batalha muitos Goitacás foram assassinados, mas uma parte daquele povo sobreviveu. Os indígenas rendidos foram levados à distante aldeia sob administração jesuíta chamada de São Pedro dos Índios, atual município de São Pedro da Aldeia. Os que não se renderam fugiram para as montanhas na direção de Minas Gerais (Noroeste Fluminense) e foram posteriormente chamados de Coropós ou Coroados. (SAINT-HILAIRE, 1941)

Quando os indígenas refugiaram-se nas florestas altas os portugueses repartiram entre si os campos de planície e dominaram completamente o território onde atualmente é a área central do município de Campos dos Goytacazes. Salvador Correia de Sá e Benevides foi nesta época um dos beneficiados com um quinhão de terra. Em 1652 o português mandou construir em suas terras uma capela consagrada a S. Salvador, e este é conhecido como o marco inicial da Vila de São Salvador. O ponto onde ficava a capela é atualmente a Igreja de São Francisco de Assis, na Rua Treze de Maio, chamada antes de Rua Direita. (SAINTHILAIRE, 1941; RODRIGUES, 1988)

Ainda no século XVIII os citadinos de Campos dos Goytacazes construíram suas casas nas margens do Rio Paraíba do Sul e também em volta da Praça Principal, perto da Igreja 
Matriz, (atualmente Catedral do Santíssimo Salvador, na Praça São Salvador). A entrada de pessoas na cidade era feita por embarcações que paravam nos portos do trecho central do Rio Paraíba do Sul. (SAINT-HILAIRE, 1941)

A carta de lei que elevou a "Villa de São Salvador" à categoria de cidade de Campos dos Goytacazes foi assinada em 1835 e é a mesma que elevou a "Villa Real da Praia Grande" à cidade de "Nichteroy" e a "Villa da Ilha Grande" à Angra dos Reis. Naquele ano o município de Campos dos Goytacazes possuía 51.718 habitantes e um ano depois, somente na parte urbana, foram computados 17.459 habitantes, 5.804 eram pessoas livres e 11.655 pessoas escravizadas (SOUZA, 2014).

SOUZA (2014) procura detalhar como era o aspecto do centro da cidade no ano de 1835, compreendido por uma praça, quatro largos, vinte ruas e seis travessas:

"A Carta de Lei do Visconde de Itaborahy veio encontrar a novel cidade da margem do Parahyba com duzia e meia de ruazinhas estreitas e tortuosas, e seis travessas, quasi todas sem pavimentação, crivadas de atoleiros, a mingua de illuminação pública, sendo esta feita por 74 lampiões de azeite de peixe, contrucções acaçapadas com respectivas rótulas e recatados "postigos", alguns solares dos barões e fazendeiros ricaços." (SOUZA, 2014,

Um mapa cartográfico da Vila de São Salvador (Figura 01, página seguinte), encontrado no departamento de iconografias da Biblioteca Nacional fornece melhores detalhes visuais sobre a estrutura do centro da cidade de Campos no início do século XIX. Não encontra-se referência ao ano de realização do mapa. Um texto manuscrito no próprio mapa informa que na vila existiam 1120 casas. Em SAINT-HALAIRE (1941), durante seus diários de viagem de 1820 temos o registro que no ano de 1816 haviam 1106 casas em Campos. A provável data do mapa, portanto, é cerca de 1820. 
Figura 01 - Mapa de Campos dos Goytacazes ${ }^{5}$

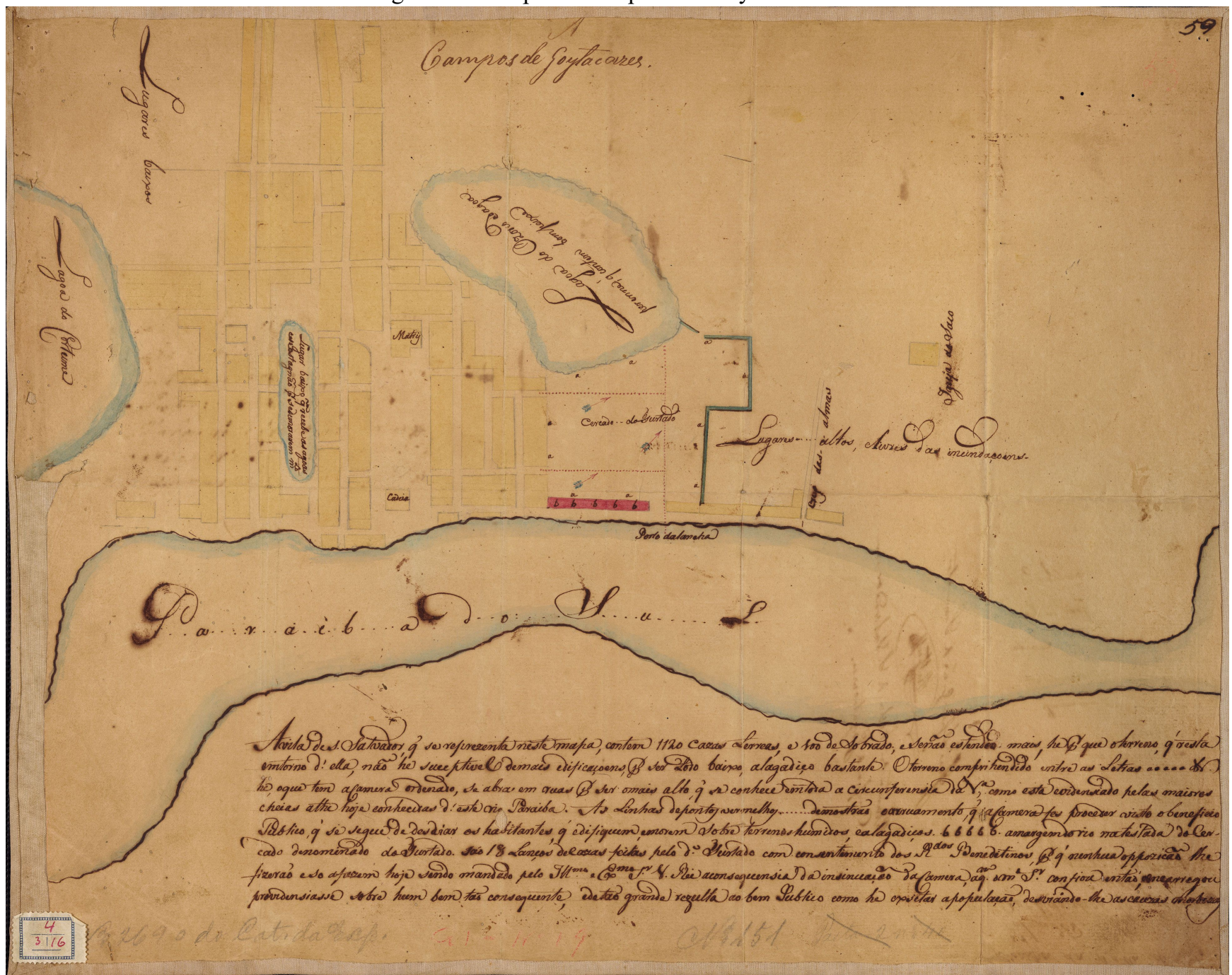

Fonte: Acervo Iconográfico da Biblioteca Nacional, sem data.

5 - O mapa, de autor desconhecido, foi feito em aquarela e nanquim e mede 33,5 x $42 \mathrm{~cm}$. Conforme mencionado no texto, desconfia-se que a data de realização seja c. 1820. Pode-se ver na imagem o Rio Paraíba do Sul. A área ocupada por ruas corresponde ao centro da cidade. Há três áreas de alagados no mapa, estas não mais existem em sua forma natural. À esquerda, quase no centro, entre duas áreas alagadas, há um quadrado onde lê-se "Matriz". Este quadrado representa a Igreja Matriz, que ficava no mesmo local onde hoje encontra-se a Catedral do Santíssimo Salvador. Em frente à Matriz, do outro lado da praça, na beira do Rio Paraíba do Sul, ficava a cadeia. Do lado esquerdo da praça (a praça é o espaço vazio entre a Matriz e a Cadeia) pode-se observar uma grande rua, uma das maiores da região central. Esta é a Rua Direita, depois nomeada Rua 13 de Maio. Na rua e em seu entorno concentravam-se as principais diversões e o comércio da cidade. O Porto Grande, localizado no início desta rua, era o maior porto do Rio Paraíba do Sul e o mais utilizado para o desembarque de pessoas da classe média, barões e monarcas. 


\section{O COSMORAMA NA CIDADE}

A palavra cosmorama é a junção de duas palavras de origem grega (kosmos e horama) e significa "vistas ou imagens do universo". As vistas reproduzidas eram "observadas pelo espectador através de um aparelho com lentes ou vidros de aumento refletidas por meio de espelhos.” (ARAÚJO, 1976, p.53). A estrutura do cosmorama era feita de madeira e a atração poderia ser ambulante ou de montagem fixa. Vale ressaltar que o espectador observava as imagens por meio das aberturas na madeira (Figura 02), de modo que cabia apenas uma pessoa por vez em cada vista. A experiência de imersão do cosmorama, portanto, era individual.

Figura 02 - Cosmorama no Rio de Janeiro

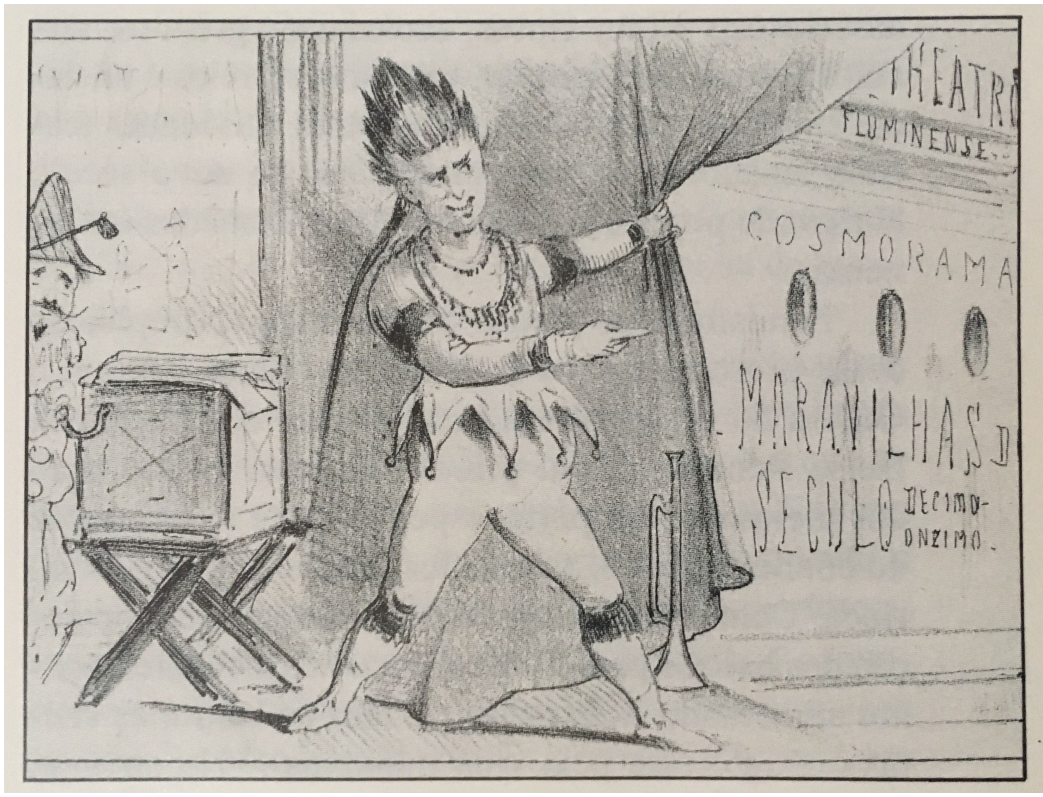

Fonte: Palácios e Poeiras, Alice Gonzaga, 1996, p. $27^{6}$

As vistas geralmente representavam cenas urbanas ou paisagens naturais dos países mais influentes da Europa e muitas delas eram reproduções de pinturas anteriormente concebidas. Os pintores daquelas vistas provavelmente utilizavam o recurso da câmara escura para captar o aspecto panorâmico e ter uma visão técnica das paisagens retratadas, pois ela oferecia "um

\footnotetext{
6 - A autora não fornece detalhes sobre a fonte primária.
} 
melhor acabamento para um cone de visão, uma encarnação de um único ponto, mais acurada que o corpo binocular e desajeitado do sujeito humano”. (CRARY, 2015, p.58)

As ideias apresentadas em CRARY (2015) esclarecem que uso da câmara escura no século XVI modificou a maneira como o ser humano concebia a visão e realizou uma operação de individuação do observador. Outra função da câmara escura foi a de "separar o ato de ver e o corpo físico do observador, ou seja, descorporificar a visão". Esta descorporificação também pode ser entendida como imersão levando-se em conta, por exemplo, o ponto de vista do observador brasileiro do cosmorama no século XIX. O estímulo das vistas e o modo de olhá-las pelo orifício fazia a mente sair virtualmente do local onde o observador encontrava-se e o levava a fazer uma viagem não-física a outros locais.

Em 25 de março de 1837, publicou-se um anúncio no jornal O Recopilador Campista sobre uma exibição de "um novo cosmorama", apresentado por Braz Bortolazz na Rua do Rosário, número 60, atual Rua Carlos de Lacerda. O texto chama atenção para a lista das vistas a serem observadas naquela apresentação, todas representavam localidades europeias. No anúncio também consta a informação de que o cosmorama faria apenas três apresentações "nos dias de festa que se seguem". Provavelmente essa festa tratava-se da comemoração da Carta de Lei que elevou a Vila de São Salvador a município de Campos dos Goytacazes, dois anos antes, no dia 28 de março de 1835.

Após os dias de festa, em 29 de março de 1837 foi publicado mais um anúncio do cosmorama no Recopilador Campista, desta vez trazendo a público que a partir de então a atração ficará aberta em "todos os domingos ou dias santos", e quando as famílias desejarem poderão solicitar uma exibição particular. O fato da atração permanecer em atividade mostra que provavelmente as três primeiras apresentações foram um sucesso e que o proprietário do cosmorama decidiu continuar explorando-o comercialmente naquele ponto. Nos anúncios 
seguintes que detalham as vistas exibidas continua claro que, mesmo alterando-se as vistas, todas representavam paisagens europeias ${ }^{7}$.

As culturas aristocrática e de classe média em Campos dos Goytacazes possuíam ideais coloniais. Faziam-se dependentes das novidades artísticas surgidas na Europa e que aportavam na capital Rio de Janeiro antes de tomar rumo ao norte-fluminense. GONZAGA (1996) explica que somente com a chegada da família real portuguesa, em 1808, é que "houve iniciativa de dotar a corte de infraestrutura de cultura e lazer" (GONZAGA, 1996, p. 27), e que durante todo o século XIX “a dependência das novidades e companhias estrangeiras, estas basicamente francesas, italianas e portuguesas, era quase que total" (GONZAGA, 1996, p. 27). O monopólio das vistas europeias nas exibições do cosmorama mostra como a imposição de determinado local/país/poder como o centro político e cultural já existia nos espetáculos das mídias pré cinematográficas.

Todos aqueles anúncios do ano de 1837 no Recopilador Campista referem-se ao mesmo cosmorama, sob apresentação de Braz Bortolazz. Encontra-se referência a este mesmo nome nos escritos de PAIXÃO (1919). O autor conta que existiu em Campos um teatro chamado Theatro Campista, inaugurado em 1832 na Rua Santa Efigênia. Seu dono, Miguel Francisco das Chagas, encarregou o artista Brazz Bortolazz, em março de 1841, de "fiscalizar o seu teatro como administrador, e fazer os ajustes necessários aos divertimentos.” (PAIXÃO, 1919, p5). Em setembro do mesmo ano o teatro fechou as portas. O que terá acontecido? A contratação de Braz Bortolazz fora uma tentativa de sobrevivência da casa? Não encontramse informações sobre que tipo de ajustes necessários e que tipo de divertimentos a casa estava buscando oferecer.

No dia 02 de junho de 1840, no jornal Monitor Campista, pode-se ler um anúncio de uma loja especializada em vidros de variados tipos, do proprietário Felicio Luraghi, 
localizada na Rua do Ouvidor n. 116, centro da capital Rio de Janeiro. Nota-se que, na loja, além de óculos e termômetros para a feitura do açúcar, também achavam-se a venda vidros para lentes de microscópio e para o cosmorama. Logo abaixo do anúncio da loja de vidros lê-se no jornal um anúncio sobre a venda de uma mulher escravizada. $\mathrm{O}$ endereço para tratarse é na Rua Direita, atual Rua 13 de maio, uma das mais movimentadas ruas do centro da cidade de Campos. Na primeira metade do século XIX o cosmorama parece funcionar como um dispositivo de imersão voltado a pessoas da classe média e alta, desejosos pelo "luxo e requinte" das grandes metrópoles europeias e, ao mesmo tempo, ignorantes aos absurdos cometidos ao redor pelo ideal colonial do Brasil escravocrata.

Na segunda metade do século XIX a cidade de Campos dos Goytacazes possuía alguns melhoramentos urbanos como ferrovias, calçamentos nas principais ruas e, em 1883, é a primeira cidade da América Latina a ter um sistema de iluminação público gerado pela luz elétrica. (SOUZA, 2014) Até 1888 a escravidão ainda era amparada pelas leis do Império do Brasil. Havia em Campos, naquela penúltima década do século XIX, ao mesmo tempo um grande número de pessoas escravizadas e várias frentes de luta pela abolição. (SOUZA, 2014)

No ano de 1880, dia 12 de fevereiro, o Monitor Campista publicou um anúncio de um "Grande cosmorama" na Rua Sete de Setembro, próximo a igreja matriz, sem qualquer menção sobre as vistas apresentadas. Numa sexta-feira, 05 de janeiro de 1883, foi anunciado no Monitor Campista o "Cosmorama das famílias". Era comum a utilização dos adjetivos "da família" ou "para a família" com objetivo de alertar que o local não exibia "cenas picantes", como eram chamadas na época as cenas que objetificavam o corpo da mulher. O cronista Mário Sette conta que havia em alguns cosmoramas "dançarinas de pernas nuas com o que embirravam as mães, rigorosas em moral, a ponto de intimidarem as filhas: - Meninas, tirem o olho daí!”. (SETTE, 1944 apud ARAÚJO, 1976) 
Também em 1883 nota-se a presença do Salão Maravilhoso, na Rua Direita n. 44. Um anúncio de 12 de fevereiro do Monitor Campista fornece detalhes sobre as diversões disponíveis na casa. O "grande polyorama ou cosmorama" promete "variada exposição contendo vistas de cidades e monumentos das 4 partes do mundo". Dessa vez não somente da Europa; ou o mundo na concepção do anunciante bastava-se na Europa? Logo a seguir o anúncio faz alarde sobre a "novidade", o "Kaleidoscopio gigante ou a lanterna mágica", contendo vistas dissolutivas, e avisa que a entrada dá direito a um prêmio "de apurado gosto". O Salão Maravilhoso provavelmente já alimentava algumas de suas atrações com o uso da energia elétrica, fato que pode ter transformado o cosmorama numa atração ultrapassada na concepção do público possuidor de tendências modernas.

As aparições dos anúncios de cosmorama em 1884 e 1885 em Campos dos Goytacazes indica decadência na popularidade daquele divertimento. Os anúncios publicados nestes ${ }^{8}$ dois anos são de tamanho pequeno, sem tipografia especial e sem a pompa encontrada nos antigos. Apenas informavam da existência do cosmorama, do seu endereço, e faziam questão de dizer que a entrada dava direito a um prêmio.

As últimas referências ao cosmorama encontradas em Campos dos Goytacazes não possuem mais o objetivo de divulgar exibições públicas. Em 1886 foram publicadas em diferentes edições do Monitor Campista quatorze cópias do mesmo anúncio sobre a venda de um cosmorama, com as "vistas, vidros e madeiramento para o assentamento". Em 1890 havia um anúncio de cosmorama à venda que figurou seis vezes no jornal, e em 1891 um "rico cosmorama" consta como um dos itens de um leilão anunciado. A perda de significância e do conceito de novidade com o público campista é perceptível. Talvez neste momento aquele dispositivo já tenha perdido a potência de imersão frente as outras inovações do fim do século.

8 O texto refere-se às publicações do Monitor Campista: 28/07/1884 (ed. 180, p.2); 02/08/1884 (ed. 180, p.2); 15/07/1885 (ed. 167, p3). 


\section{DIORAMAS E PANORAMAS EM CAMPOS DOS GOYTACAZES}

A palavra "panorama", junção do grego pan (tudo) e horama (vista) (HUHTAMMO, 2013) é atualmente bastante difundida. Serve para designar uma visão extensa e abrangente de uma paisagem real, também um tipo de fotografia digital existente em smartphones e no sentido figurado pode referir-se a um estudo ou a uma apresentação completa sobre um tema. Pouco difundido é o fato de que a palavra surgiu para designar um dispositivo de imersão em formato de rotunda (Figura 03) muito popular no século XIX.

"No panorama não havia projeção. O espectador era introduzido numa plataforma elevada, erguida no centro e à meia-altura de uma rotunda de teto cônico, e desse ponto contemplava uma grande tela pintada, estendida sobre uma parede circular. Essa vista 'panorâmica' representava uma paisagem, uma cena de batalha, um monumento ou algum assunto semelhante. Era cuidadosamente executada, com perspectiva, 'profundidade de campo' e efeitos de chiaroschuro. A tela (que na verdade não tinha fim, pois suas duas extremidades se encontravam e compunham uma cena contínua) era iluminada do alto, obliquioamente, através de uma abertura envidraçada feita no teto do edifício."

(MANONNI, 2003, p. 187)

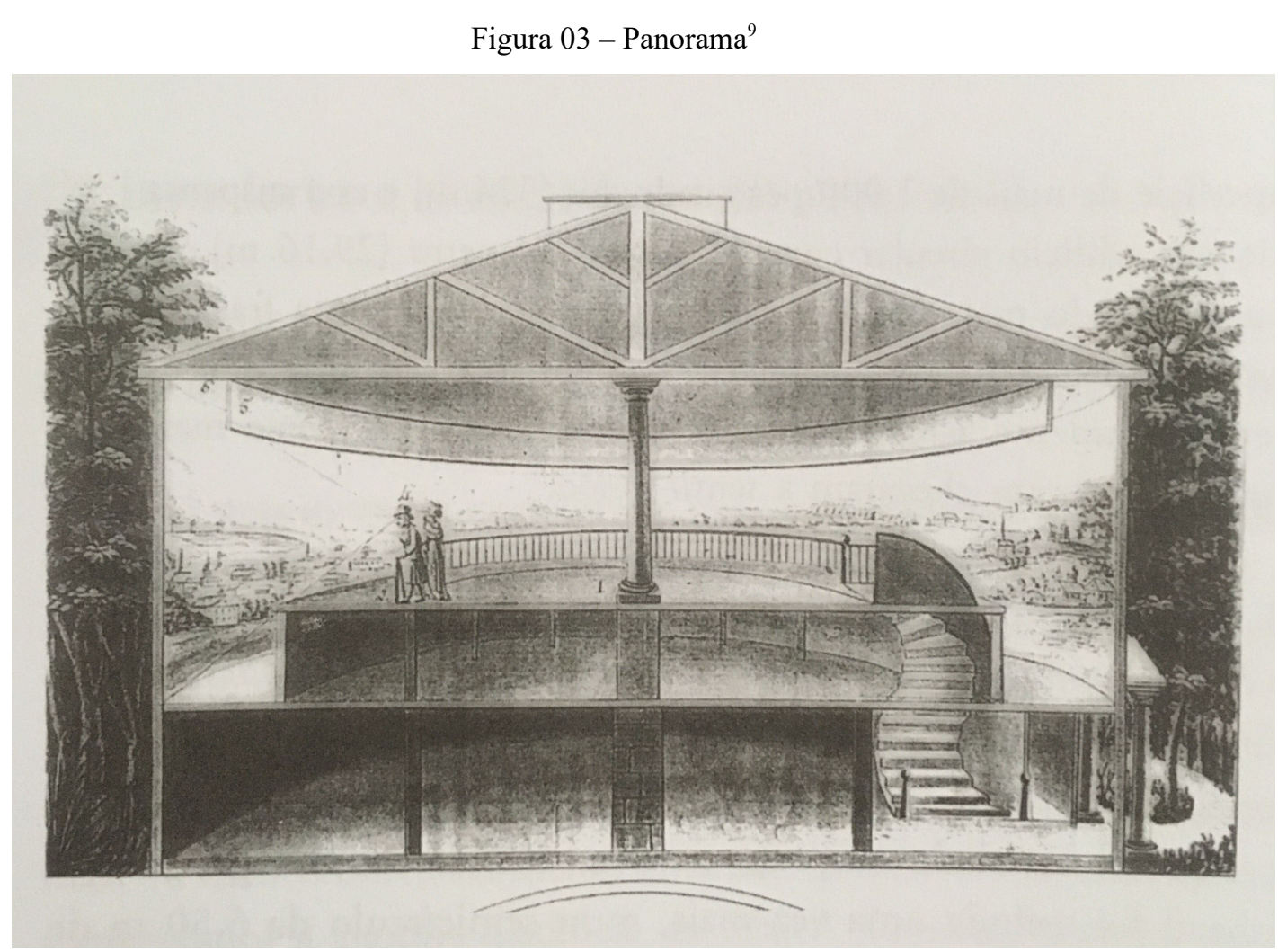

Fonte: A grande arte da luz e da sombra, Laurent Manonni, 2003, p 190.

9 - A imagem representa o desenho que acompanha a patente do Panorama de Fulton, 1799. Paris, coleção INPI. 
A estrutura circular e a possibilidade de uma visão escópica de movimentação "livre" do observador, na visão de HUHTAMMO (2013) faz do panorama um dispositivo semelhante ao contemporâneo panóptico idealizado por Jeremy Benthan. O panóptico era uma prisão em formato de rotunda onde os prisioneiros eram vistos mas não tinham a possibilidade de avistar os guardas, que ficavam acima daqueles. Os guardas eram observados por seus superiores de um ponto ainda mais alto, sem poder vê-los.

Segundo MANONNI (2003), o panorama prenunciava o sonho do espetáculo integral, da imersão do "cinema total", alcançado com os sistemas de projeção em grande escala como o Imax e os cinemas 360 graus. Já HUHTAMMO (2013) baseia-se na ideia de Michel Foucault sobre a vigilância e controle dos corpos para encarar o panorama como um dispositivo de domínio entrelaçado com o ataque do capitalismo, do imperialismo, do urbanismo e, a longo prazo, da era emergente das massas.

A palavra "diorama" é uma junção do grego "dia" (através) e "horama" (vista). O referencial utilizado para este neologismo eram as pinturas de transparência feitas para o dispositivo, mas a palavra afastou-se de seu significado original. (HUHTAMMO, 2013). O diorama apresentava pinturas que deixavam transpassar a luz. Com a mudança de intensidade e cor na fonte de luz, um movimento luminoso (como o anoitecer) parecia acontecer na tela ${ }^{10}$.

Atualmente, quando se faz uma busca em portais de pesquisa de imagens ${ }^{11}$ na web, a maioria das citações da palavra "diorama" refere-se ao significado "qualquer espécie de artesanato que utiliza miniaturas em quadros com proteção de vidro" ${ }^{12}$, bem distante da referência ao antigo dispositivo de imersão de grandes proporções.

10 - Para maiores detalhes visuais do movimento de luz recomenda-se o vídeo Le Diorama de Daguerre : reconstitution sur maquette d'une séance du Diorama Théâtre, disponível em https://youtu.be/VoCZscSBeOE .Acesso: 31/01/2020 11 - As buscas foram feitas nos portais Google Imagens e Yahoo Imagens.

12 - Este é um dos significados presentes em http://michaelis.uol.com.br/busca?id=yRlG. Acesso: 31/01/2020 
O Diorama (Figura 04) foi uma invenção pós panorama realizada por Louis Jacques Mandé Daguerre e Charles Marie Bouton. Ambos pintores e cenógrafos que faziam uso da câmara escura na produção de imagens para seus trabalhos. Daguerre ficaria conhecido posteriormente como o inventor do daguerreótipo, aparelho precursor da câmera fotográfica. "Daguerre e Bouton decidiram, em 1822, adaptar os métodos cenográficos do teatro ao velho panorama, acrescentando-lhe os efeitos especiais das caixas ópticas do século XVIII, com mudanças de luz e passagem gradual do dia para a noite (...)” (MANONNI, 2003, p. 196).

A atração do diorama costumava funcionar de forma permanente em determinado local, mas em alguns casos apresentava itinerância. Sua estrutura circular de madeira contava com uma engrenagem mecânica que proporcionava movimento à apresentação. Durante a exibição do diorama de Daguerre e Bouton os espectadores permaneciam sentados, imóveis, e a estrutura onde encontravam-se movia lentamente. As vistas do diorama não cobriam as paredes de forma integral, elas mantinham um formato panorâmico semicircular e costumavam ser exibidas em par, com uma pintura montada em cada lado da rotunda.

Figura $04-$ O Diorama $^{13}$

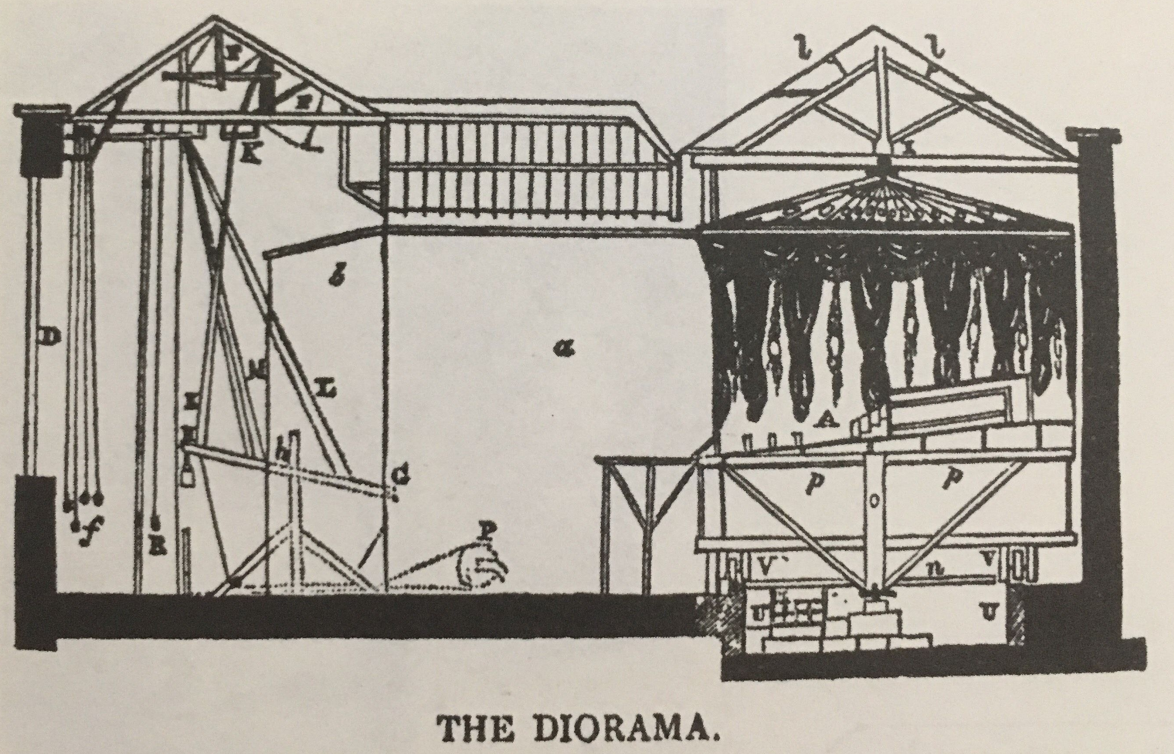

Fonte:Técnicas do Obervador, Jonathan Crary, 2015, p. 113

13 - Projeto de 1823 de um diorama em Londres. A imagem mostra a estrutura mecânica interna. 
Conforme o aparelho girava as vistas eram postas à observação do público, que adquiria a percepção de movimento. "Como a rotação era lenta, causou um dilema 'eisensteiniano": o que estava em movimento - a pintura ou o chão?” (HUHTAMMO, 2013). Em alguns dispositivos que também foram chamados de diorama, ou moving panorama (Figura 05) o mecanismo era outro: o espectador permanecia estático e a tela movia-se por uma estrutura mecânica movimentada à manivela por um trabalhador oculto ao público.

Figura 05 - O Diorama de tela móvel ${ }^{14}$

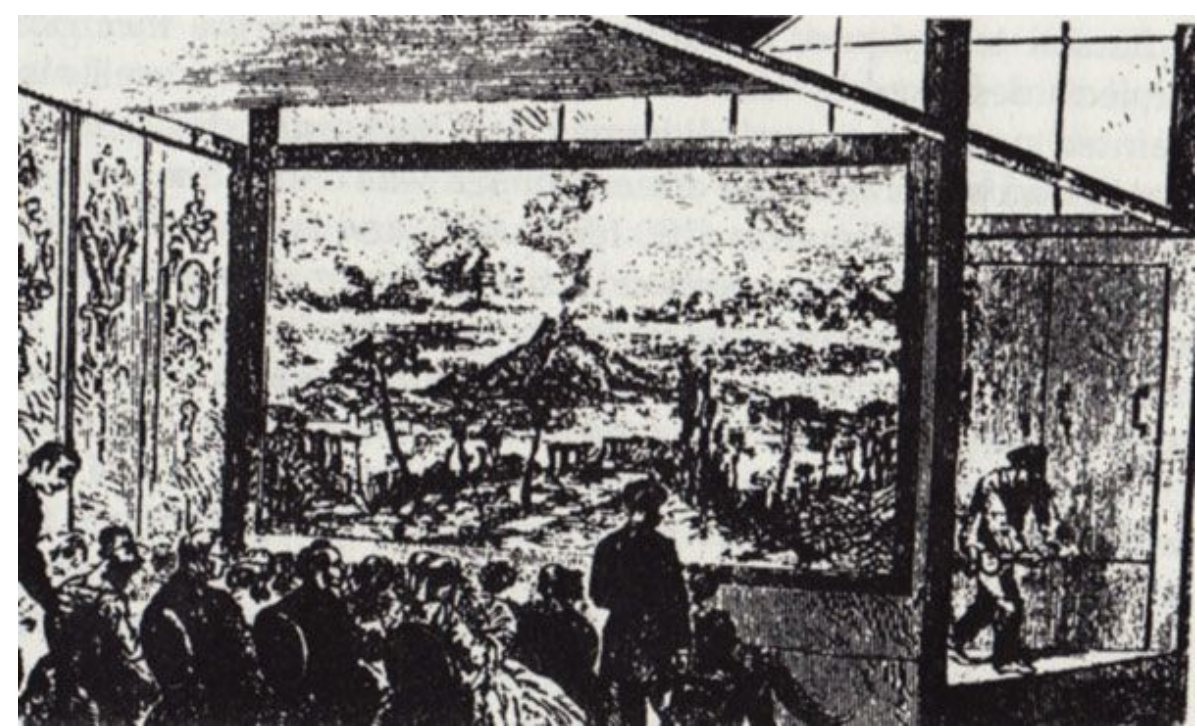

Fonte: Culture and Comunication Organization

Nota-se que o dispositivo cinematográfico também seguiu o caminho de manter o corpo do espectador imobilizado em um ambiente imersivo e a ênfase no movimento virtual da tela. $\mathrm{O}$ som é outra semelhança entre estes dois dispositivos. O diorama também pode ser considerado uma atração audiovisual quando neste eram apresentadas músicas durante as exibições. Há relatos de que a utilização do som era uma maneira de disfarçar o ruído incômodo da engrenagem mecânica geradora do movimento.

14 - A tela do diorama é desenrolada por um trabalhador que está oculto. Ano: 1848. Disponível em http://cultureandcommunication.org/deadmedia/index.php/Daguerre\%27s_Diorama . Acesso: 31/01/2020 
Em Campos dos Goytacazes, numa sexta-feira, 11 de setembro de 1840, foi publicado no Monitor Campista um anúncio sobre um diorama armado na praça principal, no canto da rua Nova d'Ouvidor. A praça principal é a atual Praça São Salvador, a rua Nova d'Ouvidor é a atual Rua Vinte e um de Abril. Esta rua era uma transversal que fazia ligação da praça com a antiga Rua Direita, a mais movimentada do centro da cidade. Aquele diorama provavelmente foi erguido no canto da praça principal que possuía maior rotatividade de público.

A estrutura física daquele diorama talvez fosse montada ao ar livre, sem forragem ou teto, ou então de sustentação muito frágil. É o que indica a observação "quando o tempo permitir" escrita no anúncio da atração. Embora a maioria dos dioramas fossem uma atração das grandes metrópoles e funcionassem permanentemente e em larga escala, versões menores, de "road-show", também existiram. Infelizmente não foi encontrada nenhuma referência às dimensões ou montagem daquele diorama que contribuíssem para o esclarecimento de como era o seu modelo arquitetônico.

Na edição de terça-feira, 15 de setembro de 1840, o diorama é novamente anunciado no jornal Monitor Campista. Mesmo endereço, mesmo preço, mesma precaução quanto ao tempo. Dessa vez pode-se ter a ideia de que as vistas são alteradas a cada exibição, pois "Este recreio, tão instructivo como divertido, continua com a exposição de novas vistas, cada vez mais interessantes". E segue a lista das vistas apresentadas, "por serem pedidas". Podese notar com esta frase o peso da decisão do público sobre quais vistas seriam expostas.

Entre as pinturas panorâmicas a serem exibidas naquele diorama notam-se "O porto Jackson" e "O rio de Paramatta", ambas em Sidney, Austrália, que na época ainda era território considerado colônia do Reino Unido. Outro quadro mostrado ao público é "A barra e bahia do Rio de Janeiro". Quem poderá ser o autor daquela vista carioca utilizada no diorama? Seria uma reprodução da obra de Félix-Émile Taunay, o "Panorama do Rio de 
Janeiro (tomado do Morro do Castelo)", de c.1830? Ou a "Vista de N. S. da Gloria et da Barra do Rio de Janeiro”, de 1839, do autor Johann Jacob Steinmann? São apenas suposições.

Ainda naquele anúncio do diorama pode-se ler os adjetivos "tão instructivo como divertido" para designar a atração. O apelo comercial promete diversão e educação unidos em um só dispositivo. Essa ideia de entretenimento educativo parece ter a mesma raiz das apresentações de "travelogues". Primeiramente no formato de relatos de viagem narrados ao vivo e acompanhados de lanterna mágica e posteriormente nos "travelogues" filmados. PETERSON (2013) define este tipo de filme como "filmes de não ficção que representam o lugar como seu tema principal. O lugar pode ser em qualquer localidade e de qualquer dimensão - de um continente a um bairro - mas o lugar é o elemento dominante.”

Quase um ano depois, em 17 de agosto de 1841, outro anúncio avisa que "acha-se aberto a grande galeria do Diorama", localizado na Rua Detraz do Terço, também conhecida como Rua da Quitanda e atual Rua Governador Theotônio Ferreira de Araújo. A atração anuncia a exposição de 16 vistas, entre elas a efígie de Dom Pedro II. A informação sobre a efígie de Dom Pedro II como uma das figuras expostas e o formato de exposição em "galeria" levam a crer que nem todas as imagens apresentadas naquele diorama possuíam estética, características e dimensões panorâmicas. Provavelmente também não eram todos os ambientes que possuíam os movimentos diorâmicos.

Em 27 de agosto de 1841 um anúncio explicita que o diorama não abre "nestes dias" porque passa por reparos para torná-lo "mais divertido, e com mais commodo", e continua, anunciando também que no local precisa-se "alugar um moleque intelligente e fiel." Muito provavelmente o "moleque" a que o anunciante refere-se era uma criança forçada a trabalhos escravos. 
O emprego do trabalho infantil em dispositivos de imersão parece ter sido comum não somente no Brasil. Uma situação parecida é retratada em uma gravura francesa com data de 1838 onde o assunto é uma apresentação de "um grande peep-show" nas ruas de Paris. Na imagem (Figura 06) em seu canto inferior esquerdo, pode-se notar a presença de uma criança de tez mais escura, que veste trajes mais simples do que as outras pessoas (estas espectadoras do dispositivo). A criança encontra-se na parte de trás da grande caixa ambulante, no lado oposto das aberturas para as vistas, e parece trabalhar durante a exibição.

Figura 07 - Trabalho infantil em um peep show na França ${ }^{15}$

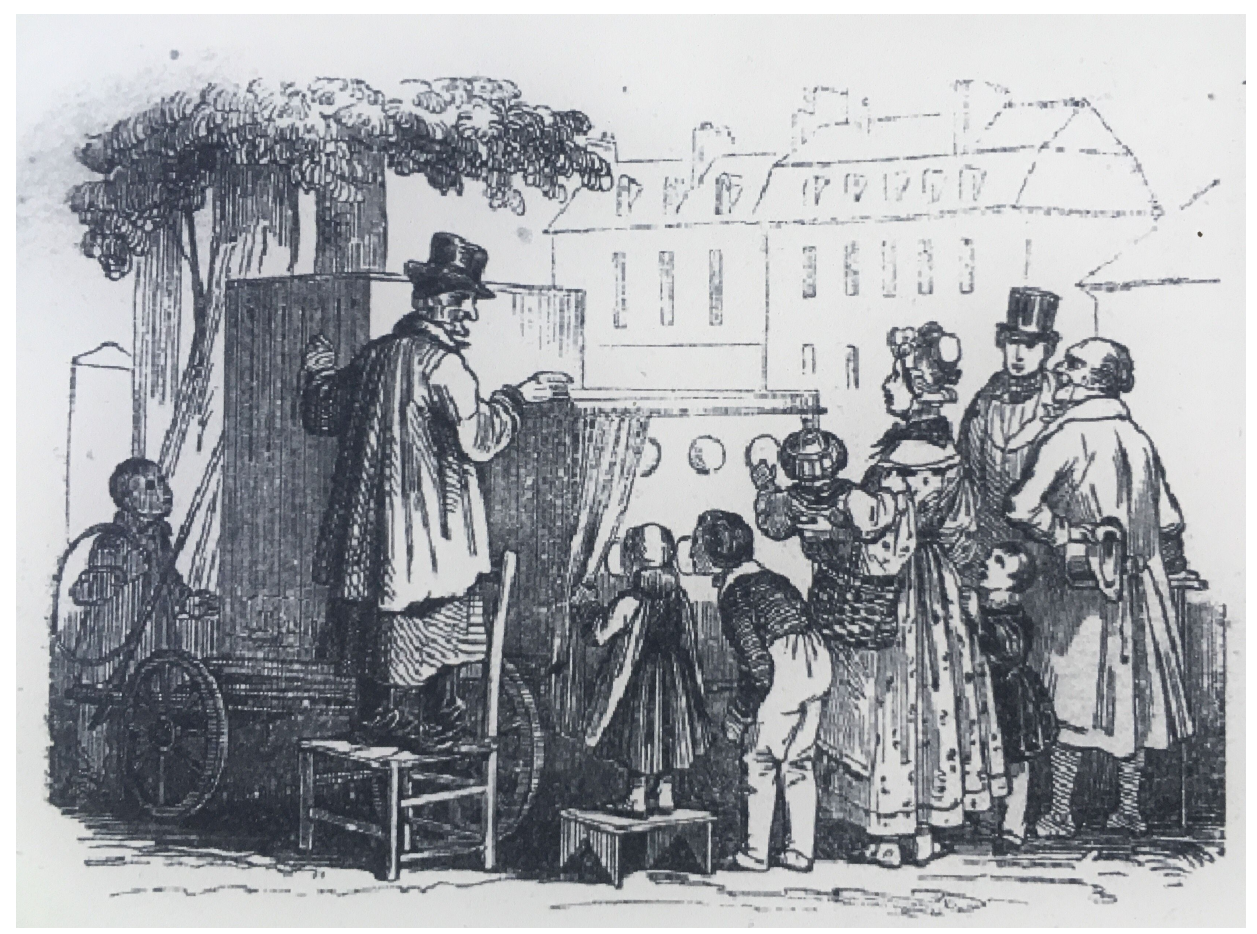

Fonte: Erkki Huhtamo, Illusions in Motion, 2013, p. 39.

Dois meses depois, na sexta-feira 29 de outubro, encontra-se no Monitor Campista mais um anúncio sobre o diorama. Desta vez a casa inclui mais uma atração, pois o título é DIORAMA E PANORAMA, e lê-se:

15 - "Large peepshow exhibited in the streets of Paris", de "Un archéologue" retirada do livro Les Grotesques. Fragments de la Vie Nomade (Paris: P. Badouin, 1838) 
"Este divertimento que, ha meses se fechou para tornal-o mais commodo, e divertido, acha-se prompto de todo; foi enriquecido de oitenta vistas, das quaes 16 serão expostas todos os dias, e algumas dellas são moventes. Apesar das grandes despesas que se fiserão, a entrada fica sendo de 160 réis por cada pessoa. Estará aberto ao publico todas as terças, quintas feiras, sabbados, e domingos; os outros dias serão destinados às famílias, que querendo ver particularmente farão favor de mandar suas ordens à Rua do Conselho n. 50." (DIORAMA E PANORAMA, Monitor Campista, Campos dos Goytacazes, 29 out. 1841, p.4)

Pela primeira vez nota-se a possível presença de um panorama em Campos dos Goytacazes. Nada se sabe sobre a armação arquitetônica deste local, nem quais eram as dimensões daquelas pinturas em exposição. É possível afirmar pelo anúncio que algumas das vistas são moventes, as utilizadas no diorama, e outras não, essas últimas seriam utilizadas no panorama. O programa promete uma grande variedade de vistas e por um preço ainda menor do que era cobrado anteriormente (o preço do ingresso antigo era de 240 réis).

A ênfase nas sessões exclusivas "para as famílias" é tão grande que o anunciante fez questão de frisar somente o endereço que utilizava para receber "as ordens" (Rua do Conselho n.50, atual Rua João Pessoa) mas não atentou-se de incluir o próprio endereço da atração. Nota-se que a oferta de vistas aumentou de número nesta atração com diorama e panorama combinados. O espetáculo parece ganhar dinamismo.

“(...) a produção do observador no século XIX coincidiu com novos procedimentos de disciplina e regulação (...) Trata-se de um corpo alinhado com e operando um conjunto de peças com rodas que giram e se movimentam com regularidade.” (CRARY, 2015, p. 112)

O diorama baseia-se na experiência de um observador imóvel que sujeitava-se a uma velocidade preconcebida pela máquina. $\mathrm{O}$ dispositivo realizava o direcionamento do olhar enquanto "descortinava" a imagem lentamente. Alguns teóricos, segundo HUHTAMMO (2013) observam tendências do mecanismo do diorama em formas posteriores de atrações midiáticas como brinquedos de parques temáticos e arquitetura giratória.

O panorama circular possibilitava maior autonomia do observador, que poderia direcionar seu olhar para qualquer ponto da imagem e escolher quanto tempo duraria esta observação. A imersão neste dispositivo parecia ser superior ao diorama. HUHTAMMO 
(2013) defende que “embora não estivesse ligado no sentido de radiodifusão ou internet, ele era capaz de teletransportar seu público para outro local, e dissolver a fronteira entre a existência local e a visão global.” (HUHTAMMO, 2013, p. 5)

O jornal Monitor Campista de 02 de novembro de 1841 apresenta mais um anúncio de título DIORAMA E PANORAMA e é quase uma cópia do anúncio anterior, a não ser por constar neste o endereço da atração e também a programação das vistas expostas. Entre as vistas, a maioria retratando cidades da Europa, nota-se a presença de "A Morte do Sr. D. Pedro $1^{\circ}$. Provavelmente o quadro trata-se de reprodução da obra de mesmo título, desenhada e litografada pelo pintor Nicolas-Eustache Maurin, em Paris, 1836. A obra em questão possui um "quadro dentro do quadro". No centro está a cena da morte do antigo imperador do Brasil e "por fora", na margem inferior, há um espaço contendo um texto descritivo do momento de sua morte. A estética utilizada na montagem do quadro narrativo é muito parecida com aquela encontrada de forma recorrente em figuras de "diários de viagem", onde a imagem é seguida de explicação.

Mais dois anúncios do mesmo Diorama e Panorama foram publicados no Monitor Campista, primeiramente na edição de 05 de novembro de 1841 e também na edição seguinte, a de 09 de novembro de 1841. Ambos de tamanho pequeno e de maneira bem resumida. Além do título, os anúncios somente avisam que a casa continua aberta e não deixam de frisar o endereço. O segundo anúncio repete o aviso de que a atração estará aberta "se o tempo permitir". Estas foram as últimas referências encontradas sobre dioramas e panoramas na cidade de Campos dos Goytacazes.

Curiosamente, acima do anúncio do Diorama e Panorama no dia 05 de novembro de 1841 pode-se ler outro anúncio que vende "Kaleidoscopos, ou marmotas d'algibeira, cujas lindas vistas varião ao infinito (...)". Tratava-se de um cosmorama portátil? Uma lanterna mágica com vistas variadas? Como mostra MANONNI (2003) existem relatos de que alguns 
caixeiros franceses da região de Saboia viajavam com seu equipamento e montavam a atração nas cidades onde paravam, e alguns destes levavam em seus ombros uma marmota viva. Não seria isso um boato que se transformou em uma lenda? Será que a caixa de madeira que esses caixeiros carregavam foi apelidada de marmota por ter cor e formato parecido com uma marmota?

O nome Kaleidoscopos também pode despertar alguma pista sobre o aparelho. Foi muito comum na Europa e America uma atração de lanterna mágica que produzia "imagens kaleidoscópicas". Pelos relatos encontrados tem-se a suspeita de que aquele tratava-se do mesmo dispositivo de projeção do espetáculo de fantasmagoria e que poderia também ser utilizado como uma potente lanterna mágica para outros fins. O sentido da denominação "Kaleidoscópio" voltou-se para o próprio aparelho. Mais detalhes sobre este dispositivo e outros truques utilizados em espetáculos de ilusão, fantasmagoria e outras atrações pré cinematográficas "misteriosas" em Campos dos Goytacazes serão tratadas no capítulo seguinte.

\section{FANTASMAGORIAS, PRESTIDIGITADORES E KALEIDOSCÓPIOS}

A fantasmagoria foi uma atração inventada no final do século XVIII (MANONNI, 2003) e que chegou com certa rapidez ao Brasil como parte integrante dos espetáculos de prestidigitadores (assim eram chamados os ilusionistas). GONZAGA (1996) comenta em nota sobre um anúncio encontrado em um jornal carioca datado de 1815 sobre a venda de uma "lanterna mágica e phantasmagorica". A atração parece ter sido muito popular em terras brasileiras durante o todo o século XIX. (GONZAGA, 1996).

A palavra fantasmagoria ou phantasmagoria é a junção das palavras gregas phantasma, que deriva de phantazô (eu faço ilusão) com agoreuô (eu falo, eu invoco). Um princípio fundamental para que a ilusão fantasmagórica funcionasse era o de que o aparato produtor da 
imagem do "fantasma", o equipamento de projeção chamado na maioria dos casos de "fantascópio", deveria ficar atrás da tela, invisível aos olhos dos espectadores. (MANONNI, 2003)

Figura 08 - Apresentação de fantasmagoria no Solar dos Capuchinhos, $1797^{16}$

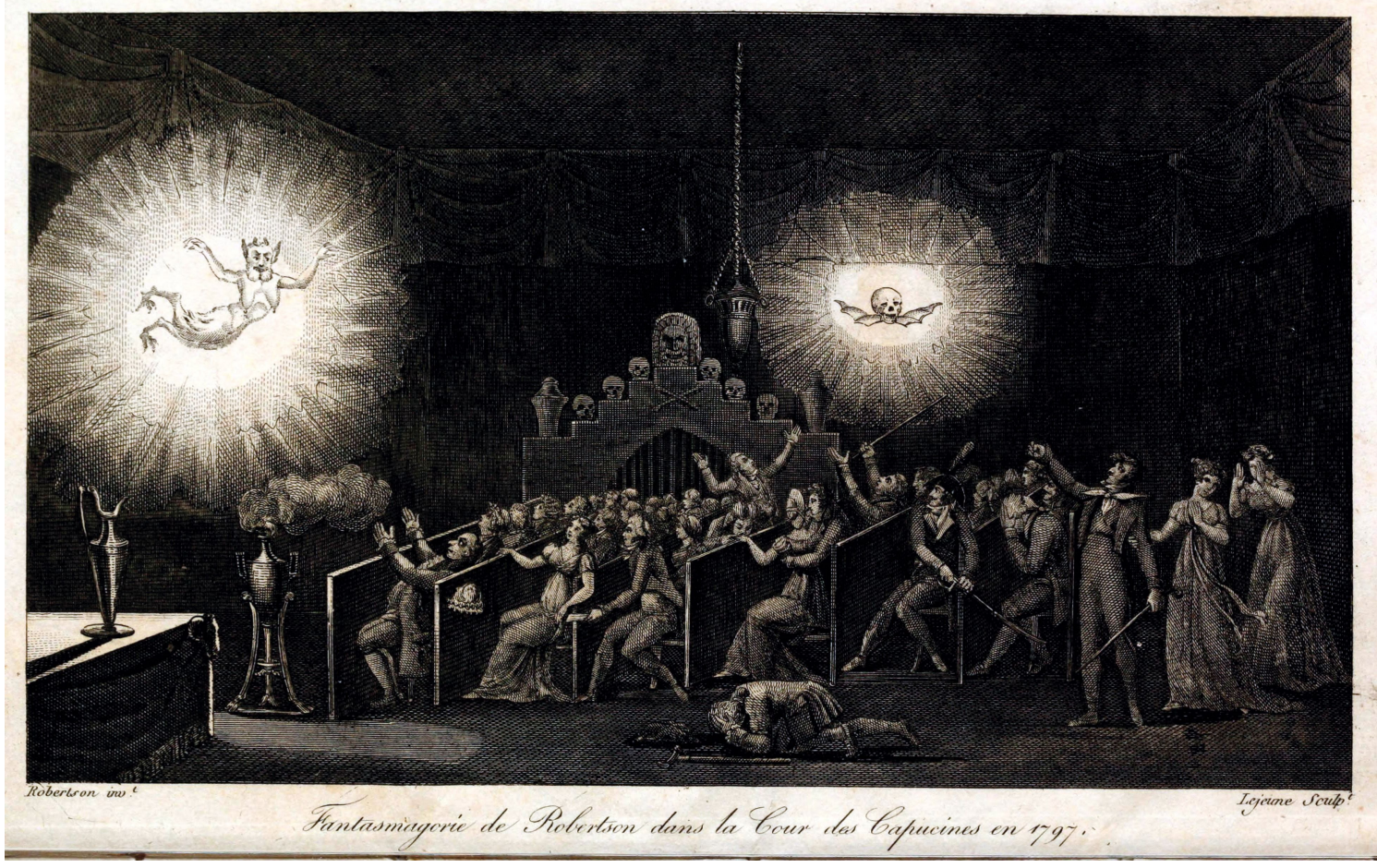

Fonte: Internet Archive

O aparelho, de concepção geralmente atribuída a Étienne-Gaspard Robertson (seu principal difusor), consistia em uma lanterna mágica de grande intensidade de luz e com mais recursos: um diafragma e um mecanismo de rodas e trilhos para o deslocamento. $\mathrm{Na}$ verdade o melhoramento da "retroprojeção móvel" já havia sido desenvolvido por Paul Philidor (MANONNI, 2003). Ao utilizar-se o recurso de movimento para frente e para trás "uma imagem (um fantasma) parecia mover-se em direção à plateia, que se encontrava encerrada em uma sala escura, criando assim um clima de espanto sobrenatural. O

16 - A imagem, publicada no livro Mémoires (1831) do próprio Robertson, retrata uma apresentação de fantasmagoria. As figuras projetadas parecem "flutuar" livres sobre as cabeças dos espectadores. Pode-se observar as pessoas espantadas. O dispositivo de projeção está oculto na imagem. Disponível em: https://archive.org/details/mmoiresrcratifss01robe/page/n8/mode/2up 
espetáculo era costumeiramente acompanhado por ruídos estranhos ou melodias macabras" (FELINTO, 2008). Nota-se a presença do som nos espetáculos de fantasmagoria como um instrumento potencializador da imersão e da ilusão.

Segundo MANONNI (2003) antes mesmo de Philidor e Robertson desenvolverem o fantascópio há relatos de apresentações de fantasmagoria em alguns locais da Europa. Uma "lanterna nebulosa", de vista fixa, muito utilizada na Alemanha, fazia a projeção de “fantasmas" em uma cortina de fumaça. O espetáculo era então chamado de "Necromancia", uma falsa tentativa de comunicação com os mortos. Geralmente uma caixa de madeira em formato de caixão era utilizada para esconder o aparato de projeção e ao mesmo tempo aumentar a sensação de medo.

No ano de 1883, ano na inauguração do sistema de luz elétrica pública em Campos, lêse na edição de 31 de outubro um grande anúncio sobre a apresentação de prestidigitação da companhia Bosco marcada para o dia seguinte no Theatro São Salvador ${ }^{17}$. O espetáculo tratase do "A mosca de ouro ou quinze minutos nos ares". "Grande scena cabalistica e cataleptica pelo magnitisador Bosco com o concurso da Sra Eugenie.” Ainda naquele mesmo anúncio lê-se a palavra "Silforama",e na linha abaixo "Produzido pela luz electrica". O silforama parece ser outro nome dado ao aparelho chamado de fantascópio ou phantascópio.

ARAÚJO (1976) cita erroneamente o "sylphorama" como uma palavra sinônima da "Inana", a atração que funcionava com espelhos e iludia o público ao fazer parecer levitar uma mulher, apelidada com este nome. O historiador traz a tona o significado da palavra: "Sylpho (gênio do ar ou imagem vaporosa) e Orama (vista)" (ARAÚJO, 1976, p. 59). Este significado encaixa-se perfeitamente na descrição das visões produzidas pelos espetáculos de "fantasmagoria" e de "necromancia".

17 - O Theatro São Salvador foi inaugurado em 1846 por iniciativa da sociedade civil campista. (PAIXÃO, 1919) Ficava localizado no cruzamento das Ruas 13 de Maio (Rua Direita) e Tenente Coronel Cardoso (Rua Formosa). O prédio foi demolido em 1919 para o alargamento da Rua Tenente Coronel Cardoso (SOUZA 1935/2014). 
No jornal Monitor Campista de 10 de novembro de 1886 lê-se uma nota que fala sobre a presença do "prestimano" Ernesto Rapallo na cidade, e que o ilusionista pretende realizar duas apresentações no Theatro Empyreo", a primeira no "próximo domingo". Nestas apresentações o artista promete a exibição do "phantascópio gigante, ou a volta ao mundo em 15 minutos". Esse aparelho provavelmente é um exemplar do fantascópio inventado por Robertson. A ênfase sobre o tempo na expressão "volta ao mundo em 15 minutos" é bem parecida com aquela encontrada no anúncio da companhia Bosco sobre a "Mosca de Ouro".

O ilusionista Ernesto Rapallo fez publicar no Monitor Campista de 10 de novembro a 12 de dezembro de 1886 o total de 13 anúncios convidando o público para seu espetáculo. Em um de seus anúncios, publicado no jornal do dia 17 de novembro, lê-se detalhes sobre a apresentação e anuncia-se que a quarta e última parte do espetáculo é realizada com a utilização do "Kaleidoscopio Cosmopolita ou o Silphorama Indiano". Esse aparelho tem grandes chances de ser o mesmo utilizado em todas as apresentações de Rapallo em Campos, mas o apelo da nomenclatura desta vez modifica-se e procura atingir um certo respaldo e exotismo com o uso das palavras "cosmopolita" e "indiano". Nota-se novamente, assim como no anúncio da companhia Bosco, o uso da palavra "Silforama" para designar o equipamento de projeção.

Na descrição do espetáculo no anúncio de 27 de novembro de 1886 tem-se uma pista de quais eram os números de mágica a serem apresentados: "Magicas! Prestidigitação! Taumathurgia! Nicromancia! Illusões! Phantasmagoria e Jogos! Gymnastica! Etc. Etc.” A última parte da programação ficava por conta do "espetaculo com o muito desejado e applaudido Kaleidoscopio. O nome desta popular atração é utilizado de maneira frequente nos anúncios.

18 - O Theatro Empyreo foi outro importante palco da cidade de Campos dos Goytacazes. Foi inaugurado em 1874 e fechou suas portas no ano de 1890. Seu prédio foi demolido três anos depois. (PAIXÃO, 1919) 
O caleidoscópio original foi inventado por Sir David Brewster em 1815. Nas ideias de Baudelaire o instrumento era uma "máquina que desintegrava a subjetividade unitária e dispersava o desejo em novos arranjos variáveis e instáveis, ao fragmentar qualquer ponto de iconicidade, interrompendo e dificultando seu estancamento.” (CRARY 2015, p. 114) Aquele “caleidoscópio de Brewster" era um dispositivo de experiência visual particular. O nome "Kaleidoscópio" mencionado nos anúncios parece referir-se ao mesmo aparelho da apresentação de fantasmagorias, mas utilizado desta vez de maneira diferente, com objetivo de alcançar outro tipo se sensação no observador.

O fantascópio, um dos nomes dados para o equipamento de fantasmagoria (Figura 09), também funcionava como uma lanterna mágica e poderia reproduzir, além de outras imagens, as populares figuras caleidoscópicas com a utilização de placas de vidros especiais chamadas de "cromatrópicas"19. Talvez por conta do sucesso da projeção destas imagens o aparelho tenha adquirido o mesmo nome daquela atração caleidoscópica. Nota-se que por conta de seu abstracionismo as imagens caleidoscópicas estão mais ligadas com a experiência do sublime do que com a imersão educativa, que procura instrução.

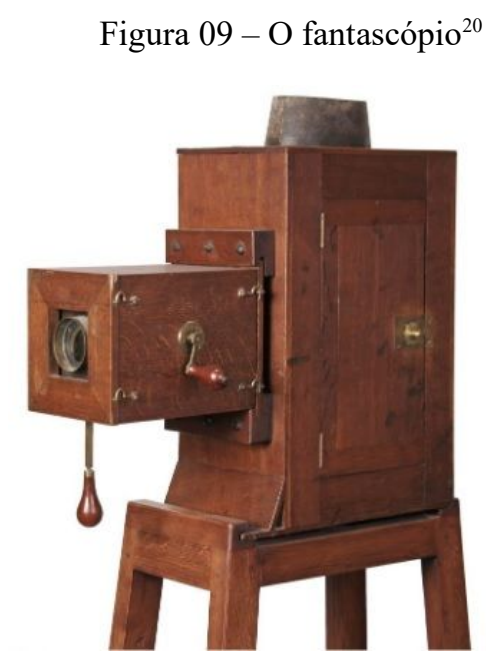

Fonte: Collection F. B., publicado por Patrice Guerrin, 2011

19 - O mecanismo cromatrópico pode ser melhor compreendido no vídeo Lanterna Magica: A Pageant of Illusions, minuto 07:42 a 08:54. Disponível em https://www.youtube.com/watch?v=w1XkqtzLfKo . Acesso: 31/01/2020

20 - Este era um dos modelos de fantascópio. Nota-se o encaixe para os vidros de lanterna mágica e as manivelas para os movimentos. http://diaprojection.unblog.fr/2011/01/21/description-et-fonctionnement-du-fantascope/ . Acesso: 31/01/2020 
Passaram por Campos dos Goytacazes pelo menos duas vezes diferentes o casal de prestidigitadores Sr. Henrique Moya e a Mme Eloise Moya. Na primeira delas o anúncio do jornal Monitor Campista de 5 de março de 1887 deixa claro que "o Sr. Moya trabalha por um systema moderno e sem apparelhos que facilitem a illusão dos espectadores." Na temporada do ano de 1898, onze anos depois da primeira, nota-se a presença do "Kaleidoscópio gigante", manuseado pela Mme. Eloise Moya em todos os dias de espetáculo no Theatro São Salvador. Muitas daquelas imagens projetadas no aparelho realizavam movimento e havia acompanhamento sonoro pelo menos em parte da exibição. Na edição do Gazeta do Povo de 23 de abril de 1898, no anúncio de estreia da agora chamada "Companhia de novidades phantasticas", explica-se que somente a Mme. Moya executava o número do kaleidoscópio, e apresentava:

"uma grande colecção dos principaes vultos Brazileiros e uma infinidade de vistas movimentadas, como sejam: Incendios, Estrellas Diamantinas, Cromatropicas, Estatuas dos mais notaveis escultores, Montanhas de Gêlo, Rios, Paisagens e muitas outras bellezas. [...] (Na apparição de alguns dos principais vultos da grande Nação Brazileira será tocado o magestoso HYMNO NACIONAL)" (GAZETA DO POVO, Campos dos Goytacazes 23 de abril de 1898, p.3)

As vistas "cromatrópicas" e de "estrellas diamantinas" faziam referência às imagens caleidoscópicas. Pensando nestes quadros como raízes do que viriam a ser os gêneros cinematográficos, pode-se observar o caleidoscópio em movimento como uma raiz do cinema experimental ou abstrato. Ousando um pouco mais pode-se buscar semelhanças entre o anseio dos espectadores do kaleidoscópio e os dos atuais espectadores do cinema quando estes vislumbram os espetáculos quase pirotécnicos dos filmes de super-herói.

Poderíamos considerar as vistas de "Estatuas dos mais notáveis escultores" como parte do gênero documentário instrutivo, muito próxima também de programas de TV sobre arte e 
cultura. Do gênero "travelogue" foram apresentadas as vistas "Montanhas de Gêlo"21, "Rios", "Paisagens", e "muitas outras belezas".

Ainda no espetáculo de Mme Eloise Moya foram projetados retratos de importantes nomes da república brasileira, com acompanhamento sonoro do hino nacional. Este "gênero" lembra as projeções de lanterna mágica que eram realizadas por ambulantes da região de Sabóia, durante a Revolução Francesa, final século XVIII. "O repertório dos saboianos veiculava as reivindicações do povo. (...) as vistas projetadas são ataques violentos à realeza, e os comentários que os acompanham, irônicos e insolentes.” (MANONNI, 2003, p. 115). No caso das projeções de Mme Moya, as vistas não atacavam os monarcas, mas exaltavam as grandes personalidades republicanas.

Na edição de 15 de maio de 1898 do Gazeta do Povo lê-se na primeira página uma cobertura detalhada sobre o espetáculo de prestidigitação do casal Moya em benefício da Santa Casa. No Kaleidoscópio de Mme Moya “como de costume appareceram os retratos de diversos homens ilustres, entre elles Floriano Peixoto, Manoel Victorino e Carlos de Lacerda - o inolvidável abolicionista. Toda sala victoriou enthusiasticamente estes tres notaveis vultos de nossa patria."

No dia 20 do mês de novembro de 1891, sete anos antes da segunda aparição do casal Moya em Campos, lê-se no jornal Monitor Campista um comentário da coluna Theatros e... sobre a chegada em Campos dos Goytacazes do prestidigitador sul americano Professor Kij, "filho da adiantada Columbia, a república americana que relembra o nome do descobridor deste continente." A coluna passa a informação de que o Professor Kij “em pleno vigor da idade, de olhar vivo, fronte larga e intelligente", visitava Campos depois de exibir-se "perante selecto auditorio, em Santa Thereza, capital federal".

21 - Nota-se um grande número de paisagens de gelo e outras áreas inóspitas ou de difícil acesso em quadros da lanterna mágica e em relatos de viagem. 
Informações sobre atividades do Professor Kij em São Paulo deixam claro que uma de suas atuações profissionais envolvia a importação de aparelhos inovadores da companhia de Thomas Edison para exibições e venda no Brasil. Kij, em 1895, exibiu um Kinetoscópio de Edison na Confeitaria Paulicéia ${ }^{22}$. Em Campos dos Goytacazes ele apresentou-se em 1891 como um grande prestidigitador proveniente do Theatro Robert-Houdin de Paris. Em anúncio prometeu apresentar na "Grande soirée phantastica" números de "hypnotismo e espiritismo simulado", "maravilhas do mundo fantástico" e "prestidigitação humorística".

O número "espiritismo simulado" deve ser outro nome dado aos espetáculos de "necromancia" ou "fantasmagoria". A palavra "simulado" deixa a pista de que o espectador saberia tratar-se de uma apresentação falsa, criada por algum aparato técnico. Os pioneiros Paul Philidor e Robertson já seguiam os preceitos do iluminismo em suas apresentações e faziam questão de alertar o público sobre o fato de que aquele espetáculo era uma ilusão.

"O objetivo do espetáculo era sempre declaradamente o de desfazer as 'crenças absurdas, os terrores pueris, que desonram a inteligência do homem". Não obstante com habitual ambiguidade, Robertson guardava para si o método de criar os fantasmas e espectros que exibia à assistência. O objetivo da fantasmagoria era potanto dúbio: ele buscava muito mais amedrontar do que dissipar o obscurantismo" (MANONNI, 2003 p.

A apresentação "maravilhas do mundo fantástico" também é encontrada no anúncio do Prof. Kij e provavelmente tratava-se de um número imersivo utilizando-se da potente lanterna mágica para mostrar vistas de paisagens, desta vez sublimes e surreais. A proposta de imersão em uma "viagem sem sair do lugar" com destino a um local de cenário "misterioso e fantástico" tem raízes de grandes semelhanças com as do cinema. A comparação mais óbvia pode ser feita com filmes de fantasia e terror, mas de maneira mais abrangente pode-se fazer um paralelo das vistas de paisagens fantásticas com a própria ideia do cinema de ficção, do não-real.

22 - Informação apresentada por José Inácio de Melo Souza em Nova História do Cinema Brasileiro, Vol. 1, Editora Sesc, 2018. 
ELSAESSER (2018) afirma que a fantasmagoria pode ser encarada como um dispositivo que vai além do cinema, pois a atração também está fundamentada na evocação do passado no presente e em uma "estética de aparência enquanto presença". O evento do presente e o local físico tem aqui mais importância do que na situação cinema. $\mathrm{O}$ pesquisador ainda afirma que a fantasmagoria tem relação com a instalação artística, "que não precisa de moldura ou mesmo orientação vertical e para frente" (ELSAESSER 2018 p.132) Observando a fantasmagoria a partir da arqueologia das mídias esta pode ser estudada como uma mídia ancestral relacionada ao videomapping. Esta possui relação intrínseca com a situação do evento e com a área de projeção que é livre do retângulo, geralmente baseada nas estruturas físicas do próprio suporte que a recebe. 


\section{CONSIDERAÇÕES FINAIS}

Durante toda a pesquisa procurou-se relacionar as atrações pré cinematográficas dos cosmoramas, dioramas, panoramas e fantasmagorias ocorridas em Campos dos Goytacazes com o cinema e outras mídias. Isto não significa que as especificidades daqueles dispositivos não foram respeitadas. Gêneros cinematográficos como os filmes de travelogue, ficção científica e filmes de super-heróis foram levantados e relacionados à percepção visual e auditiva das antigas vistas exibidas nos diferentes meios.

O trabalho também buscou comparações entre o funcionamento dos antigos aparelhos de imersão com dispositivos da atualidade. Os cosmoramas podem então ser observados como um dos propagadores do gênero de viagem, ou travelogues, tido como gênero instrutivo e educativo. Ainda no cosmorama nota-se a presença do gênero pornográfico. A visualização individual proporcionada pelo aparelho parece ter favorecido a popularidade daquele tipo de temática. O dispositivo pode ser ainda relacionado aos óculos de realidade virtual (ou óculos VR), levando-se em conta a questão da experiência visual de imersão solitária, que objetiva apenas o olhar e ignora o restante da experiência perceptiva.

Os panoramas são tratados como dispositivos que realizam o sonho da imersão total e que vão inspirar a criação do Cinerama, Cinemascope, e outros dispositivos cinematográficos panorâmicos e de grande formato. Infelizmente poucos são os detalhes sobre panoramas exibidos em Campos e a escassez de informação não contribuiu para a tomada de conclusões sobre as imagens exibidas e as experiências dos espectadores campistas. As conclusões sobre o dispositivo contribuíram em alguns casos para o entendimento do diorama, analisando-se as diferenças e semelhanças.

Talvez o diorama tenha impressionado seus espectadores por conta da realização de movimentos de luz e de travelling, muito próximo do que viria a ser o cinema. Abundantes 
foram as vistas de paisagens exibidas nos dioramas em Campos, o que faz deste dispositivo outro propagador do gênero travelogue. Outra importante contribuição do diorama está na tentativa de aproximar suas apresentações ao status de arte, o que também pode ser notado até hoje no cinema. A utilização de interatividade do corpo com o dispositivo mecânico durante a exibição no diorama pode ser relacionada a diversos aparelhos como brinquedos de parque de diversões ou o chamado Cinema $4 D$, que possui simulação de movimento.

As fantasmagorias, por sua característica do mistério, não tinham apresentação detalhada nos jornais. A relação da fantasmagoria com o cinema do gênero terror é óbvia por conta da inclusão de criaturas bizarras nos enredos do cinema. Como mostra FELINTO (2008), a relação vai além quando o cinema de terror também faz uso específico daquela sensação fantasmagórica original, que é o movimento de invocação e aproximação da criatura. O filme japonês Ringu, refilmado em Hollywood com o título O chamado, é um exemplo que encaixa-se perfeitamente neste tipo de utilização. A pesquisa ainda buscou aproximar a especificidade do dispositivo (a projeção livre das amarras do retângulo e ao mesmo tempo intrínseca ao espaço) com a projeção mapeada, ou videomapping.

O cinema aproveitou muitos métodos e características destes antigos dispositivos de imersão. Até hoje os aparelhos midiáticos entrelaçam suas raízes e reaparecem de novas formas. Continuam a surgir novos dispositivos, que ao primeiro olhar parecem transcender o cinema, porém, numa visão mais aprofundada, todos ainda mantém aquela velha característica de domínio sobre os corpos humanos. Permanecem então as perguntas de ELSAESSER (2018) "Onde está o cinema?", “O que é o cinema?" e "Pra quê serve o cinema?”. 


\section{REFERÊNCIAS BIBLIOGRÁFICAS}

ARAÚJO, Vicente de Paula. A Bela Época do Cinema Brasileiro. São Paulo: Editora Perspectiva, 1976.

CRARY, Jonathan, Técnicas do Observador: Visão e modernidade no século XIX, Rio de Janeiro: Contraponto, 2015.

ELSAESSER, Thomas Elsaesser. Cinema como arqueologia das mídias, São Paulo:

Edições Sesc São Paulo, 2018.

FELINTO, Erick. A Imagem Espectral: Comunicação, Cinema e Fantasmagoria

Tecnológica, Cotia: Ateliê Editorial, 2008.

GONZAGA, Alice. Palácios e Poeiras: 100 anos de cinemas no Rio de Janeiro. Rio de Janeiro: Record: FUNARTE, 1996.

HUHTAMMO, Erkki. Illusions in Motion: media archaeology of the moving panorama and related spectacles. Massachusetts: MIT, 2013.

MANONNI, Laurent. A grande arte da luz e da sombra: arqueologia do cinema, São Paulo: Editora SENAC São Paulo: UNESP, 2003

PAIXÃO, Múcio da. Os theatros de Campos. Rio de Janeiro: Typ. Almeida Marques \& C., 1919.

PETERSON, Jennifer Lynn. Education in the School of Dreams: Travelogues and Early Nonfiction Films. Durham e Londres: Duke University Press, 2013

RODRIGUES, Hervé Salgado. Campos: Na Taba dos Goytacazes. Niterói: Imprensa Oficial, 1988

SOUZA, Horacio. Cyclo Aureo: Historia do $1^{\text {o }}$ centenário de Campos 1835 - 1935. Campos dos Goytacazes: Essentia, 2014 (reedição da obra original de 1935).

SANT-HILAIRE, Augusto de. Viagens pelo Distrito dos Diamantes e Litoral do Brasil, São Paulo, Porto Alegre, Recife: Companhia Editorial Nacional, 1941. 


\section{REFERÊNCIAS HEMEROGRÁFICAS}

Avisa-se aos habitantes dessa cidade, Monitor Campista, ed 019, p.3, 02 jun. 1840.

B. Bortolazz. Monitor Campista, Campos dos Goytacazes, ed.218, p.4, 29 mar. 1837.

Cosmorama. Monitor Campista, Campos dos Goytacazes, ed.217, p.4, 25 mar. 1837.

Cosmorama. Monitor Campista, Campos dos Goytacazes, ed.228, p.4, 03 mai. 1837.

Cosmorama. Monitor Campista, Campos dos Goytacazes, ed.236, p.4, 31 jun. 1837.

Cosmorama. Monitor Campista, Campos dos Goytacazes, ed.119, p.3, 28 mai. 1890.

Cosmorama das famílias. Monitor Campista, Campos dos Goytacazes, ed.07, p.4, 11 jan. 1883.

Diorama. Monitor Campista, Campos dos Goytacazes, ed. 046, p.6, 11 set. 1840.

Diorama. Monitor Campista, Campos dos Goytacazes, ed. 047, p.4, 15 set. 1840.

Diorama. Monitor Campista, Campos dos Goytacazes, ed. 137, p.4, 17 ago. 1841.

Diorama. Monitor Campista, Campos dos Goytacazes, ed. 140, p.4, 27 ago. 1841.

Diorama e Panorama. Monitor Campista, Campos dos Goytacazes, ed.158, p.4, 29 out. 1841.

Diorama e Panorama. Monitor Campista, Campos dos Goytacazes, ed.159, p.4, 02 nov. 1841.

Diorama e Panorama. Monitor Campista, Campos dos Goytacazes, ed. 161, p.4, 09 nov. 1841.

Escriptorio commercial. Monitor Campista, Campos dos Goytacazes, ed.168, p.4, 21 jul. 1886.

Espectaculo. Monitor Campista, Campos dos Goytacazes, ed.250, p.3, 31 out. 1883.

Grande cosmorama. Monitor Campista, Campos dos Goytacazes, ed.041, p. 4, 12 fev. 1880

Leilão. Monitor Campista, Campos dos Goytacazes, ed.295, p.3, 27 dez. 1891.

Prestidigitador. Monitor Campista, Campos dos Goytacazes, ed. 261, p.3, 10 nov. 1886.

Salão Maravilhoso. Monitor Campista, Campos dos Goytacazes, ed.037, p.3, 12 fev. 1883.

Telegramma. Monitor Campista, Campos dos Goytacazes, ed.276, p.3, 27 nov. 1886.

Theatros e. Monitor Campista, Campos dos Goytacazes, ed.270, p.1, 1891.

Theatro Empyreo. Monitor Campista, Campos dos Goytacazes, ed.267, p.3, 17 nov. 1886.

Theatro S. Salvador. Gazeta do Povo, Campos dos Goytacazes, p.3, 23 abril 1898.

Theatro S. Salvador. Gazeta do Povo, Campos dos Goytacazes, p.1, 15 mai. 1898.

Theatro S. Salvador. Monitor Campista, Campos dos Goytacazes, ed.059, p.3, 05 mar. 1887.

Theatro S. Salvador. Monitor Campista, Campos dos Goytacazes, ed.0270, p.2, 20 nov. 1891. 


\section{ANEXO A - ANÚNCIOS DE COSMORAMAS}

\section{COSMORAMA}

Braz Bortolazz tem a honra de faser blico, que elle tem estabelecido nesta $\mathrm{c}$ de em a rua do Rosario $n$. $60 \mathrm{um}$ novo $C$ morama onde exporá ricas, e magnificas tas, e tera lugar pela $1 .^{*}$ vez, hoje 20 corrente, e bem assim todos estes 3 segu tes dias de festa, desde as 7 horas da tar até as 10 da noite; sendo o preço da enl da 320 rs. por pessoa:

\section{VISTAS.}

1." Os salteadores de Hespanha atacse uma carroagem.

2." Os ditos obrigando os roubados, af sar-lhes uma claresa.

3." A fónte de S. ${ }^{\text {ta }}$ Sofia em Constantí pla, no dia de sua grande festa.

4. A- Praça de París com a coluna Vendorf, que Napoleão fez construir $\mathrm{cm}$ bronze.

5." $\Lambda$ Pastôra dos Campos de Alemá 6." O Porto da Cidade de Amestardan
Q⿻ 丿3 B Bortolazz faz publico, que o Cosmorama estará aberto, (de hoje emo te) todos os Domingos, e dias Santos deg da; e quando qualquer familia quiser particularmente, pơderão dirigir-se ao nunciante para traf́ar.

Monitor Campista, ed.218, p.4, 29 mar. 1837

p.4, 25 mar. 1837.

COSMOR.AMA.

O Proprietario deste intertinimento $p 2$ tecipa ao Respeitavel Fublico, que amanh 4 do corrente estará aberto o seu Cosmort ma, e que appresentará as vistas seguintes:

1. A Praça do commercio de Milano co a magnifica casa de commercio, e escadari de marmore: he um dos edificios da Italiae que atrahe admiração dos viajantes.

2." Vista do Porto e Cidade de Magot ça, no Reino de Holanda.

3." As ruinas do Castello de Valença t França.

4." e 5." As duas estampas dos salteadore

6. A Praça de París, con a columma i Vendome. n.

\section{COSMORA MA.}

O Proprietario deste intertinimento tecipa ao Respeitavel Publico, que Sexta ra 2 de Junho, e Domingo, estará abert seu Cosmorama com as seguintes, e novaV I S T A S.

1. A grande Cidade do Porto.

2." O Foburgo de Doge na Holanda.

3." Prito de Doisam na França

๑, 4." Atpracia de Conmercio de Milano

$5^{4}$ As rumas do Castello de Valenç 1

Monitor Campista, ed.236, p.4 31 jun. 1837 
B A A iza-se aos habitantes desta cidade, -que, no Rio de Janeiro rua do ouvidor n. 116 na loja de Felicıo Luraghi, se acha um com. pleto sortimento de oculos de alcance, ditos para nariz, de todas as qualidades e vistas, microscopios de grande augmento, vidrus para cosmorama, thermometros para a fabricação do assucar, e outros muitos instrumentos per. tencentes a este ramo de negocio: acha-se na mesma caza un grande sortimento de realejos de todos os tamanhos, e com as arias e hymuos mais modernos e gosto do paiz, o que tudo se vende por modico preço.

Q5 Quem quizer comprar uma escrava de 18 a 20 annos muito sadia, e q'entende de todo o serviço de uma casa, lava, engomma, e coze alguma couza; á vista do conprador se dirá porque se vende: na rua Direita n. 12.

\section{Grande cosmorama RECREIO PAMILIAR \\ A' RUA SETE DE SETEMBRO \\ Vioinho da isteja siatriz \\ O proprietario deste recreio con- vida as Exmas. familias e ao publico para visitarem este bello e aprazivel divertimento. \\ Preço da entrada 500 rs. com di- reito a um premio. \\ Abre-se todos os dias ás 7 horas da noite.}

Monitor Campista, ed.0417, p.4, 12 fev.1880.

Monitor Campista, ed.019, p.3, 02 jun.1840

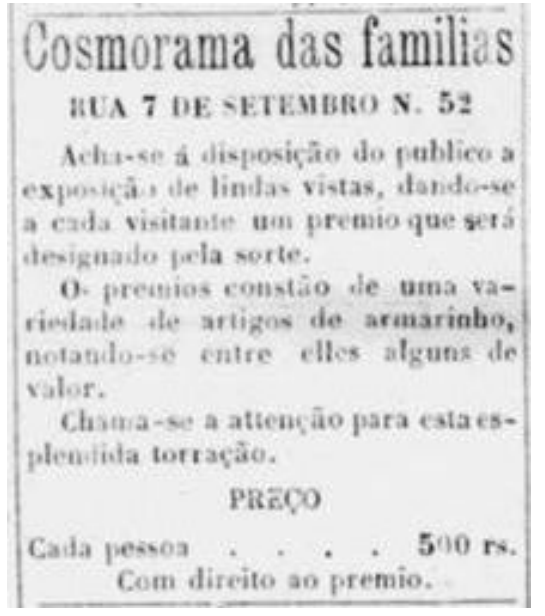

Monitor Campista, ed.07, p.4, 11 jan. 1883

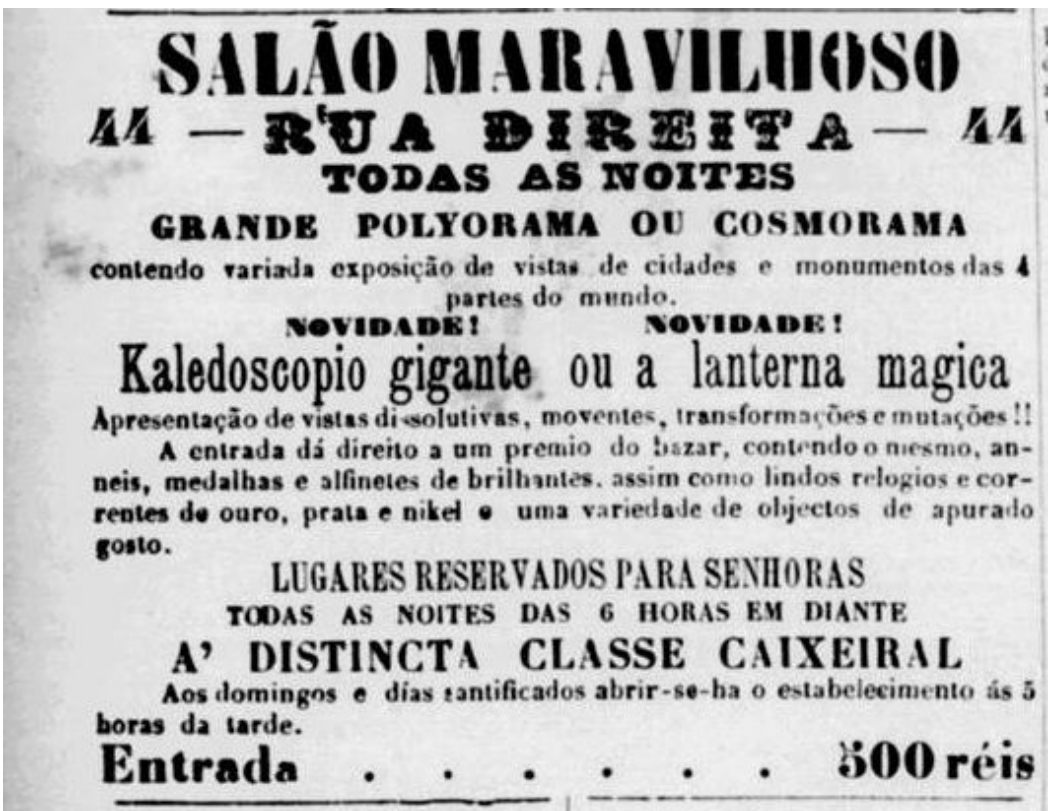

Monitor Campista, ed.037, p.3, 12 fev. 1883 


\section{COSMORAMA}

HOJE ! HOJE ! HOJE ?

Chegou a esta cidade um magrifico o sorprehendente COSMORAMA, composto de vistas das principaes cidades, parques, jardins, edificios e combate3, da Europa e America, o qual será franquiado hoje au respeitavel publico.

Entrada geral . . . $500 \mathrm{rs.}$

N. B.-Todas as entradas terāo direite a uma sorte.

RUA FORMOSA N. $1 \mathrm{G}$

Monitor Campista, ed.167, p.3, 15 jul. 1885

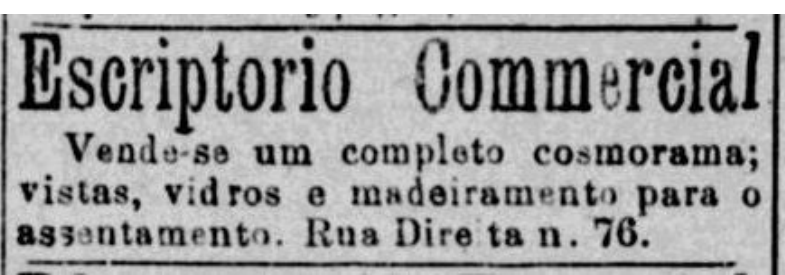

Monitor Campista, ed.166, p.4, 21 jul. 1886

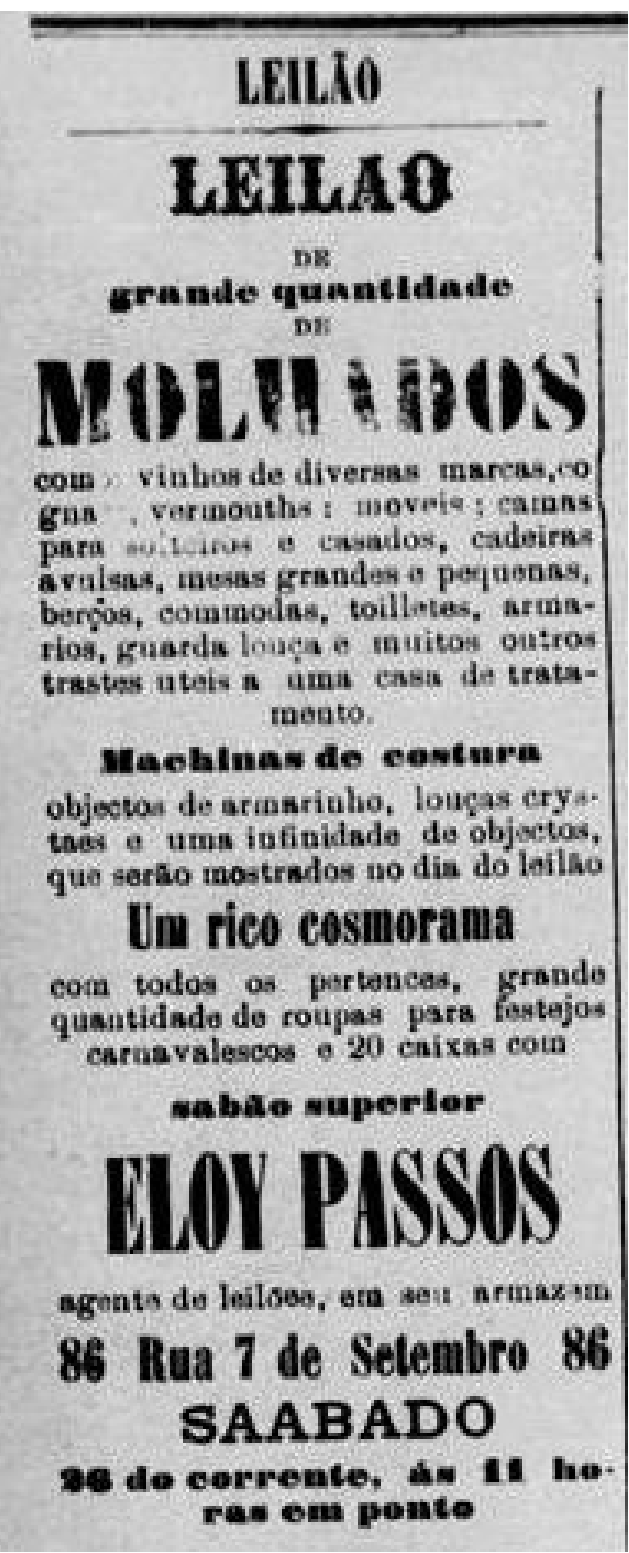

Monitor Campista, ed.295, p.3, 27 dez. 1891 


\section{ANEXO B - ANÚNCIOS DE DIORAMAS E PANORAMAS}

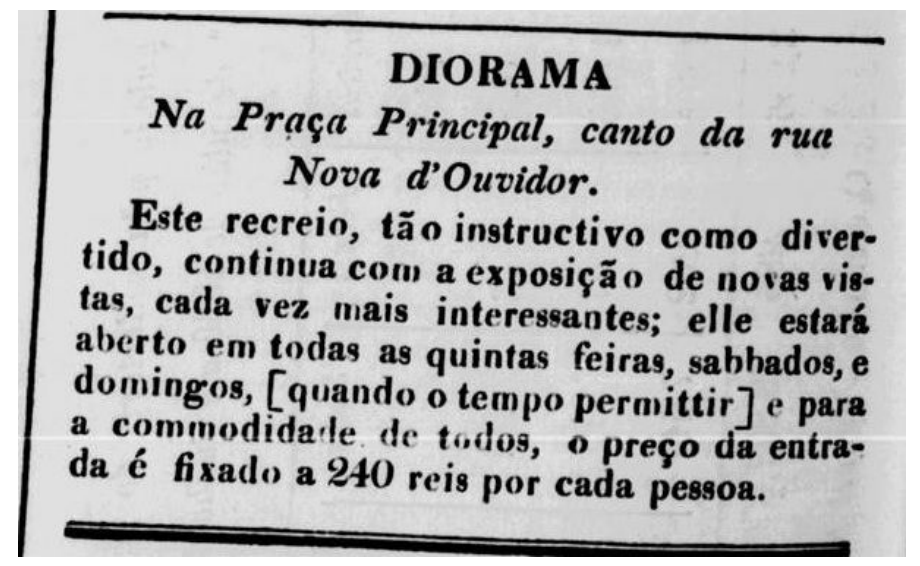

Monitor Campista, ed.046, p.6, 11 set. 1840.

\section{DIORAMA}

\section{Na Praça Principal, canto da rua Nova d'Ouvidor.}

Este recreio, tảo instructivo como dicer. tido, continua com a exposição de novas vis. tas, cada vez mais interessantes; elle estará aberto $\mathrm{em}$ todas as quintas feiras, sabbados, $\mathrm{e}$ domingos, [quando o tempo permittir] e principiará ás 7 horas da noite.

Achão-se expostas as ricas vistas seguintes: por serem pedidas.

1.-O porto Jackson.

2." -O rio de Paramatta.

3." - A cidade de Lisboa.

4. - O jardim do palacio real em Paris.

5. $-A$ ponte e cidade de Bordeaux.

6 "-A. barra e bahıa do Rio de Janeiro.

7. - A cidade d'Ha vre de Grace em França.

8. - A cidade e porto de Trieste.

Preço da entrada 240 reis.

$$
\text { TYP. PAT. DE R. J. P. DA G. E ABREU. }
$$

Monitor Campista, ed.047, p.4, 15 set. 1840.

Q Kaleidoscopos, ou marmotas d'algibeira, cujas lindas vistas varião ao infinito, vendem-se por commodo preço na loja desta Typ. Praça das Verduras n. 30: •

DIORAMA E PANORAMA. Rua \& Quitanda $n \mathbf{4 5}$.

Continúa a estạg aberto emos dias já annun. ciados. $\therefore$

Monitor Campista, ed.160, p.4, 11 mai. 1841.

\section{DIORAMA.}

Acha-se aberto a graffle gal rit do Dioraina, composta de 16 vistas nui inchs, entre as quaes se acha a effigie de S. M. I. of Sr. D. Pedro 2. o mais proprio, que te'n a orrecido, na rua de Traz elo 'Terço n. 45.-1 क्? A entrada é 240 rs,por cada pessoa.

Monitor Campista, ed.137, p.4 17 ago. 1841.

\section{$\checkmark:$ DIORAMA:}

Precisando dialguns prepáros, para o tornar mais - divertido, e on nua commodo, não se abre estes dias, porem logo, que esţ̣ja prompto se fará os competentes anuunçios: no mesmo precisa-se alugar um moleque intelligente, ê lie!.

Monitor Campista, ed.140, p.4, 27 ago. 1841.

\section{DIORAMA E PANORAMA.}

Este divertimento que, ha nreseg se fecbon para tornal-o mais commodo, e cuivertido, acha-se prompto de tódo; foi enriquérido de oitenta vistas, das quaes, 16 serāo expostas tó dos o dias, e algumas dellas são -moventes. - A pesar das grandes despezas que se fiserāo, a en- trada fica sendo de roo réis por catha pessoa, Estará aberto áfypublico em todaseas terças, quintas feiras, sablados, e doming os; os outros dias serão destinádos ás fa múlias, que querendo ver particularimente, farä̀ favor de mandar as suas galens á rua do Conselho n. 50.

Monitor Campista, ed.158, p.4, 29 out. 1841. 


\section{ANEXO C - ANÚNCIOS DE PRESTIDIGITAÇÃO E FANTASMAGORIAS}

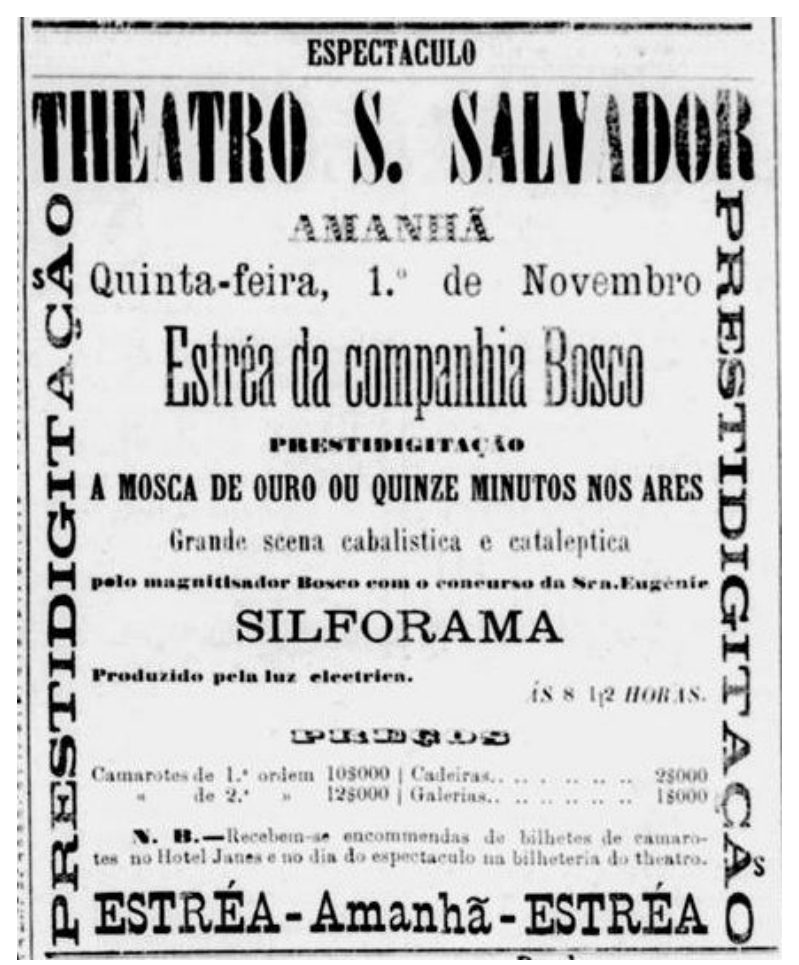

Monitor Campista, ed.250, p.3, 31 out. 1883

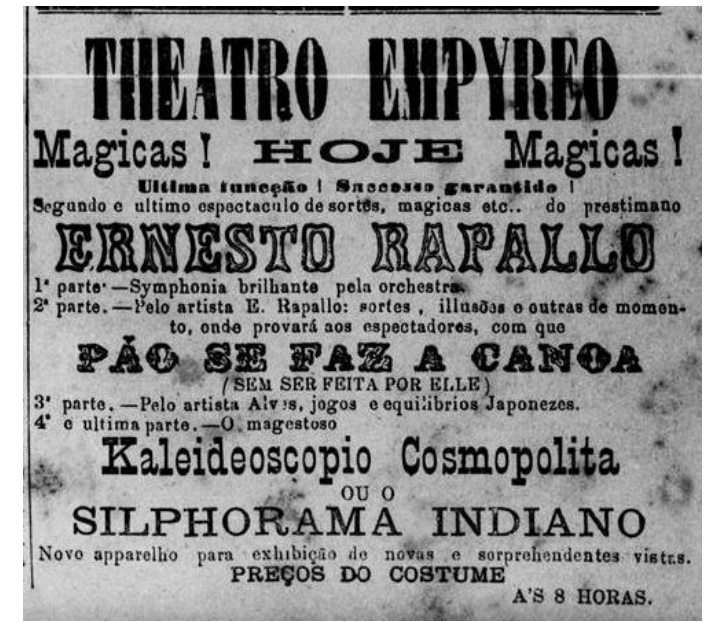

Monitor Campista, ed.267, p.3, 17 nov. 1886

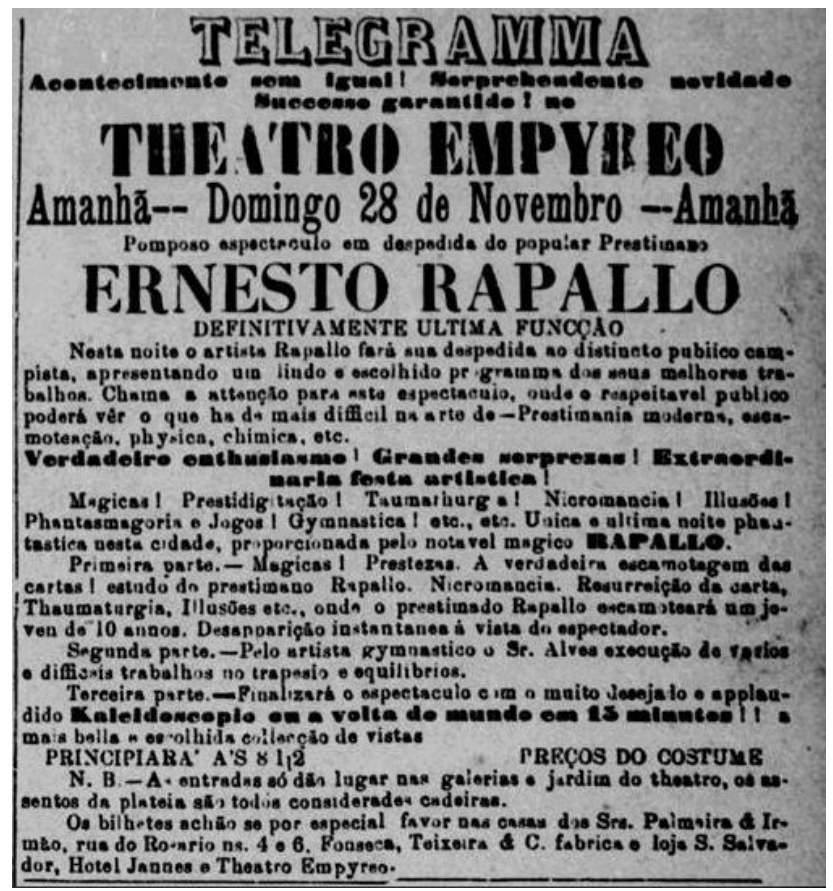

Monitor Campista, ed.276, p.3, 27 nov. 1886 


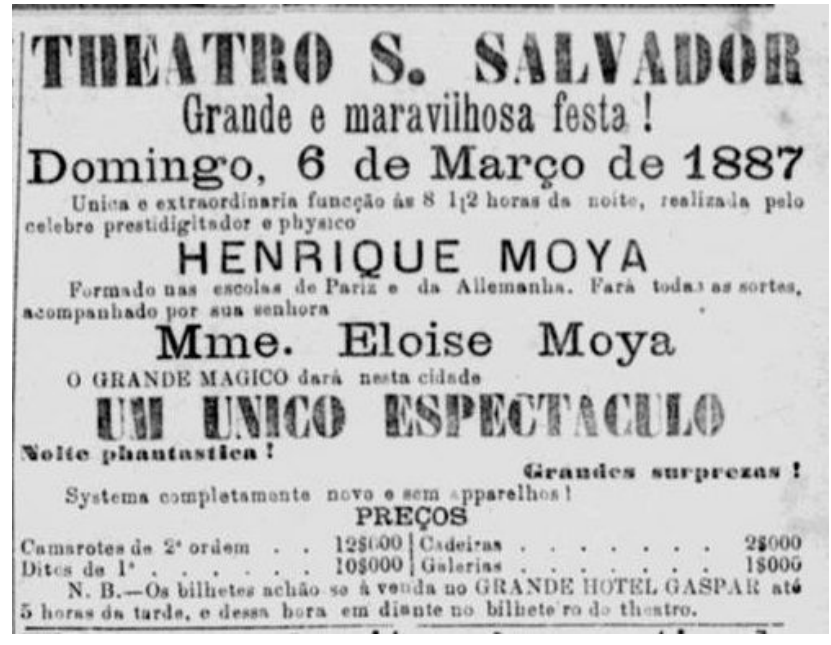

Monitor Campista, ed.053, p.4, 05 mar. 1887

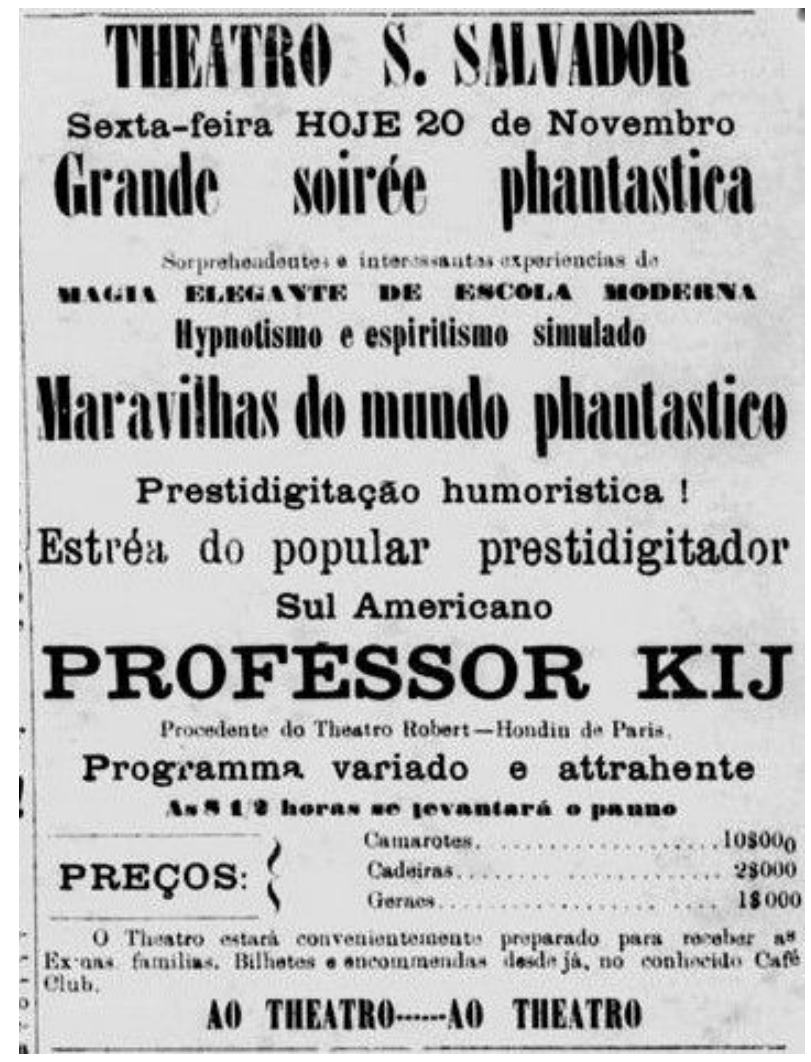

Monitor Campista, ed.270, p.3, 20 nov. 1891.

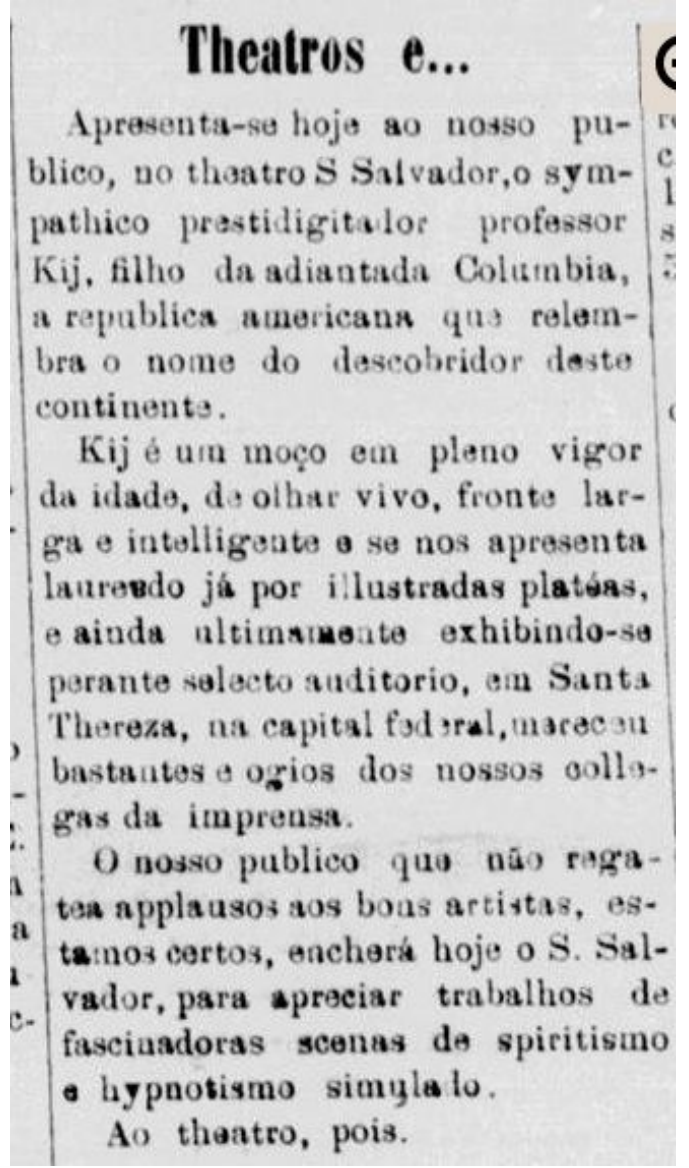

Monitor Campista, ed.270, p.1, 20 nov. 1891. 


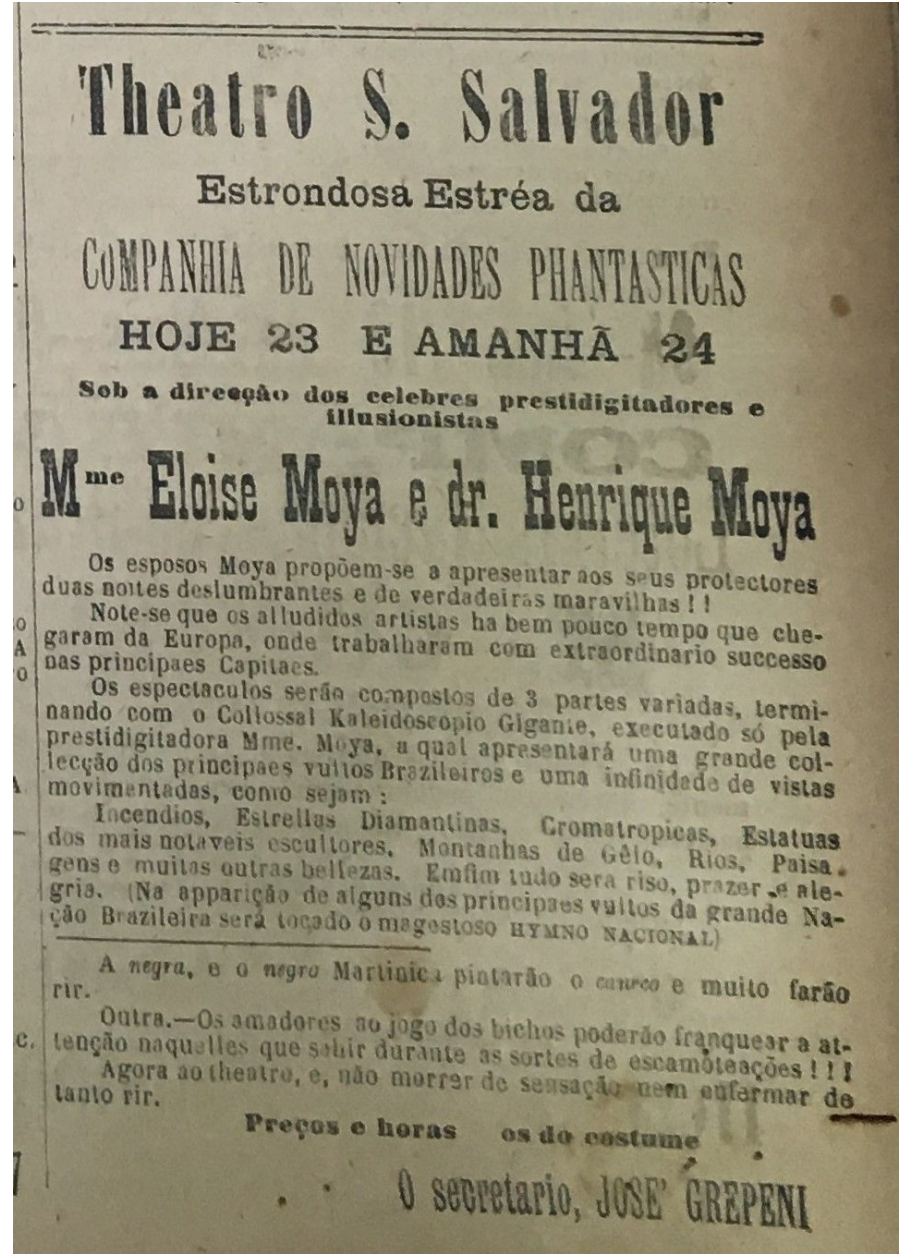

Gazeta do Povo, p.3, 23 abr. 1898.

\section{THEATRO S. SALVADOR}

Foi um completo successc o beneficio realisado em favor dos cofres da Santa Casa.

O theatro estava litteralmente cheio, vendo-se nas cadeiras, camarotes e varan las elegantes senhoras $\theta$ senhoritas, que davam um tom brilhante o garrido á festa.

Uma enchente colossal.

Foi representada a sala encantada pelo dr. Moya, que como de costume fez sortes lodas muito applaudidas.

Madame Bernabei cantou dous trechos de opera e a actriz Fontana algumas cançonetas.

O publico applaudio-as. Soguio-se o kaloidoscopio, dirigido por madame Eloyse Moya, sendo exhibidos lindos quadros, como os das sconas da Semana Santa, muito aprecíados.

Como de costume apparece. ram os retratos de diversos homens illustres, entre elles Floriano Peixoto, Manoel Victorino o Carlos de Lacerdao inolvidavel abolicionista.

Toda a sala victoriou enthusiasticamente estes tres notaveis vultos da nossa patria.

Nos intervallos tocaram as bandas de musica, Lora de Apollo o Operarios Campistas.

Gazeta do Povo, p.1, 15 mai. 1898. 